\title{
Characteristics of Earthquakes Recorded Around the High Dam Lake with Comparison to Natural Earthquakes Using Waveform Inversion and Source Spectra
}

\author{
Hamada Saadalla, ${ }^{1}$ Abdel-Aziz Khairy Abdel-aal, ${ }^{1,3}$ Abdelnasser Mohamed, ${ }^{1}$ and K. El-Faragawy ${ }^{2}$
}

\begin{abstract}
To determine whether recent seismicity around the High Dam Lake (Lake Nasser) in the Aswan region is induced or triggered by the lake reservoir or is of natural origin, we analyzed moment tensor solutions and source spectra of recent recorded earthquakes in the area. The earthquakes' focal mechanisms, including source mechanism parameters and source spectra, can give important information to assist in discriminating between triggered and natural seismic events. In the current work, we computed moment tensors and stress drop values for six recently triggered earthquakes recorded by the Egyptian National Seismic Network (ENSN) around Lake Nasser, Aswan area, with local magnitudes between 3.0 and 4.6, as well as 40 nearby earthquakes in and around Egypt with local magnitudes ranging from 4.0 to 5.5, that are known as natural events. We performed full waveform inversion for the studied seismic events, including the dominant double-couple (DC) signature, and also completed moment tensor solutions. Our results show that most triggered events demonstrated significant non-double-couple components. The focal depths of most Aswan seismic events calculated in the current study are significantly shallower than the estimated focal depths for interplate and intraplate earthquakes in and around the area under investigation. The focal depths of $80 \%$ of the triggered events are shallower than $10 \mathrm{~km}$, while $80 \%$ of the tectonic earthquakes are deeper than $15 \mathrm{~km}$. On the other hand, stress and source spectra of the studied events are used as another key to deeply study the source mechanics and physics of natural and triggered events in this area.
\end{abstract}

Keywords: Aswan-triggered seismicity, moment tensor inversion and decomposition, stress drop, Lake Nasser.

Electronic supplementary material The online version of this article (https://doi.org/10.1007/s00024-020-02490-4) contains supplementary material, which is available to authorized users.

1 National Research Institute of Astronomy and Geophysics (NRIAG), Helwan, Cairo, Egypt. E-mail: hamada_geologist2010@ nriag.sci.eg

2 Geology Department, Faculty of Science, Aswan University, Aswan, Egypt.

3 Kuwait Institute for Scientific Research, Safat, Kuwait.

\section{Introduction}

Aswan earthquakes are regarded as triggered seismicity (Gahalaut and Hassoup 2012), controlled by the pressure of pore fluid due to the water impoundment in the second largest reservoir in the world, Lake Nasser. McGarr et al. (2002) distinguished between induced and triggered earthquakes; the first, "induced" earthquakes, where human activity is responsible for the most energy required for failure, and the second, "triggered" earthquakes, where anthropogenic activity is much smaller than the shear stress causing a fault to slip. Gupta (2002) pointed out that the seismic activity resulted from the impoundment of lake water as a secondary factor, in areas where the tectonic activity plays a primary role, would be classified as triggered earthquakes. Kebeasy and Gharib (1991) suggested that Aswan seismicity is controlled by three main factors: pre-existing complex faults system, water load, and the pressure of pore fluid. In this research, we utilized the source parameter model to study the source characteristics of the Aswan seismic zone (triggered earthquakes) as well as nearby inter- and intraplate seismic events in and around Egypt. Many studies have been conducted to evaluate the fault plane solution for all seismic zones in Egypt (e.g., Hassib 1997; Abou Elenean 2003; Hussein et al. 2013). There is not yet a detailed study including the inversion and decomposition of full waveform moment tensor into double-couple and non-double-couple components in Egypt. Natural earthquakes are expected to have a shear faulting mechanism with a high double-couple (DC) component, whereas a notable non-DC component is an indicator of non-shear faulting and suggestive of another physical process, such as tensile faulting, 
pore fluid effect, rock burst, volcanic eruption, or geothermal processes (Cesca et al. 2013). Lizurek (2017) observed that most of the seismic events in the area of Czorsztyn Lake have at least $20 \%$ of non-DC components, and they concluded that full moment tensor inversion is a practical technique for distinguishing reservoir-triggered earthquakes from natural and purely induced seismicity. Mixed shear faulting and non-DC components are indicators of areas where induced seismicity occurs in a geothermal field (Ross et al. 1996; Guilhem et al. 2014). Coseismic volume change in the source region is a dominant feature of earthquakes induced by fluid injection and explosion sources (Zhao et al. 2014). Seismic events in complex faulting zones are the causative factor in generation of the compensated linear vector dipole (CLVD) component (Kuge and Lay 1994). Combination of isotropic and deviatoric components of moment tensors are characters of tensile failure and source processes of volcanic events (e.g., Foulger et al. 2004; Templeton and Dreger 2006). Static stress drop is another parameter suggesting an earthquake's source and can be a useful tool in the investigation of the source characterization of natural and reservoirtriggered seismicity. Several studies suggest that reservoir-induced seismicity may have a lower stress drop value than those of a tectonic origin (e.g., Fehler and Phillips 1991; Gibowicz et al. 1991; Abercrombie and Leary 1993). In the current research, we limited our analyses to discriminate between Aswan seismicity and those of tectonic origin in Egypt based on full moment tensor solutions and decomposition into a DC part and compensated linear vector dipole part. In addition, we calculated the static stress drop of a mixed data set including triggered and natural seismic events using the spectral inversion technique. This work focuses on the Aswan seismic region located in the southwestern part of Egypt (Fig. 1a), a region where the 14 November 1981 earthquake with local magnitude 5.6 occurred along the Kalabsha fault (60 km southwest of Aswan High Dam). A recent study by Mohamed et al. (2009) in the target area proposed that the seismic events with depth less than $5 \mathrm{~km}$ are triggered by fluid-saturated heterogeneous rock matrices, where $\mathrm{P}$-wave velocity and a higher Poisson ratio was observed. In contrast, the deeper seismic events are more of tectonic origin.
Also, the mentioned study noticed that the fault ends are the source zone for stress accumulation and earthquake generation. Telesca et al. (2017) studied Aswan earthquakes based on a statistics-based seismicity approach and concluded that the loading and unloading operation of Nasser Lake reservoir affected the time dynamics of both deep and shallow earthquakes. Many studies eventually conducted to evaluate the static stress drop have obtained low stress values (e.g., Saadalla et al. 2019; El-amin 2011; Mohamed 2004; Hassib 1997). In this study, we focus on a regional and local data set in and around Egypt, recorded by the Egyptian National Seismic Network (ENSN) from 2010 to 2017 (Fig. 3a, b). The data is composed of about 1400 earthquakes which are considered in previous studies as reservoir-triggered seismic events that took place in the Aswan area. Aswan seismic events are mostly microearthquakes, with only six earthquakes having a local magnitude $>3$ during the studied period. In addition, 40 earthquakes occurred along other seismic zones in Egypt, such as the Red Sea, Triple Junction, Gulf of Aqaba, and scattered seismicity in the crust, which are natural earthquakes. All the mentioned data will be involved in the evaluation of the stress drop, and only the earthquakes with magnitude $>3$ will be involved in the moment tensor inversion and decomposition analyses.

\section{Geological and Tectonic Setting}

The western desert of Egypt is characterized by subdued highs (desert plateaus) and flat rocky expanses of lowlands and depressions. It starts west of the Nile River and extends into Libya to the west, to Sudan to the south, and covers an area of $681,000 \mathrm{~km}^{2}$ (Said 1962). The Aswan seismic region is located within the Western Desert between latitude 23.00 and $24.25 \mathrm{~N}$ and longitude $32 \mathrm{E}$ and $33.35 \mathrm{E}$, approximately $60 \mathrm{~km}$ southwest of Aswan High Dam (Fig. 1a). According to the topography of the area, this area is comprised of a few principal geomorphological provinces: the Nile River Valley, the Nubian plain, the Sinn el-Kaddab plateau, and the Sinn el-Kaddab plateau escarpment. This region represents a stable shelf of clastic and carbonate 

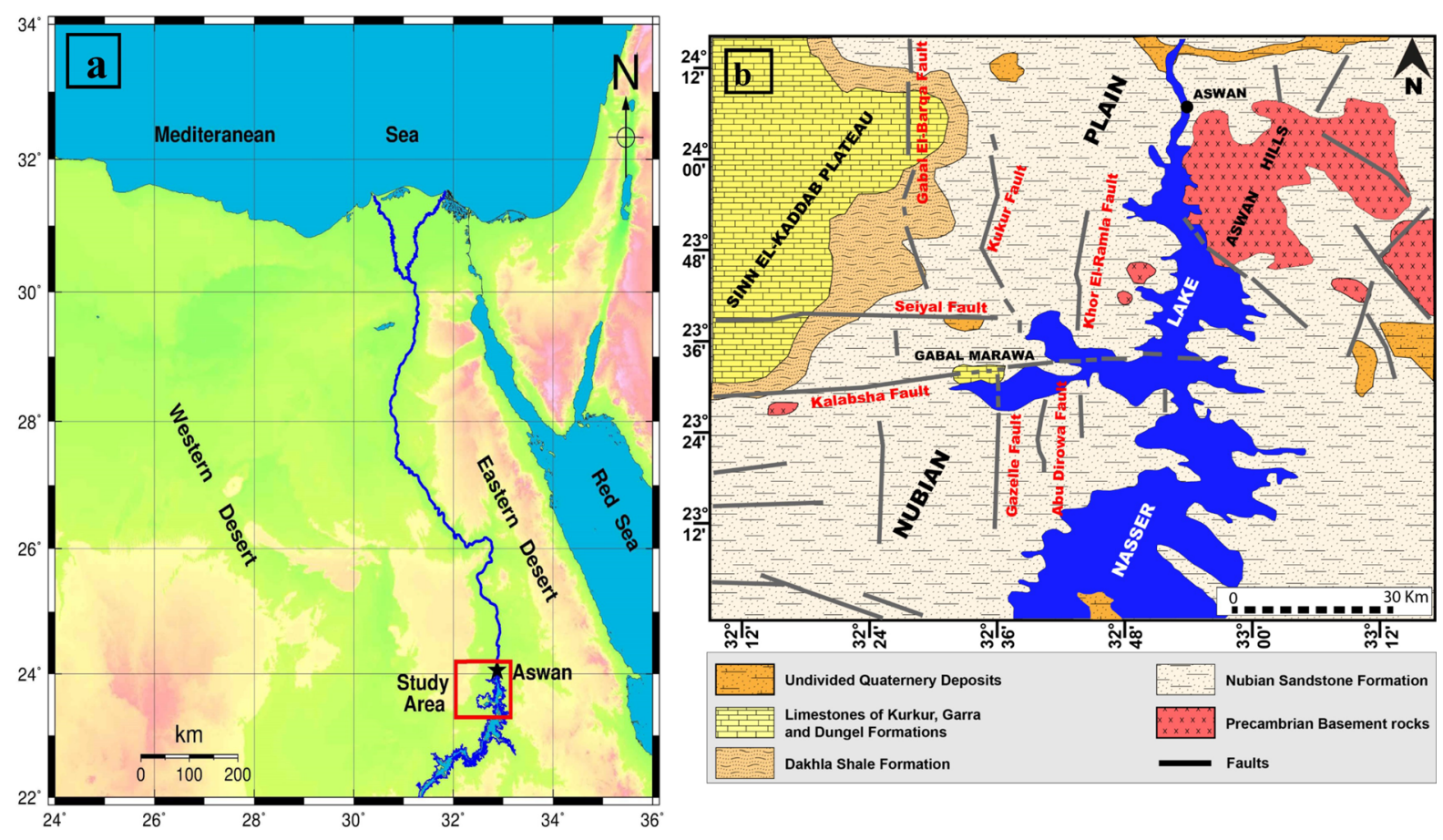

Figure 1

a Location of the study area. b Geology, geomorphology, and tectonic setting of Aswan region, modified after EGSMA (1981)

rocks accreted to the crystalline Arabian-Nubian Shield that is skirted by a belt of the unstable shelf of deformed sequences of shallow- and deep-water sediments (Youseff 2003). The geological strata represented within the study area consist of nearshore, shallow-, and deep-water sedimentary rocks that range in age from Late Cretaceous, Tertiary and Quaternary conglomerates, and gravel deposits, all of which overlie a Late Precambrian granite basement (Jerris 2014). The sedimentary sequences deposited on the stable and unstable shelf range in age from Late Cretaceous (Maastrichtian) to Lower Eocene. The Nubian plain extends from the Nile River to the eastern escarpment of the Sinn el-Kaddab plateau to the west. This stretch ranges from 30 to $50 \mathrm{~km}$ wide until it reaches the southern extent of the plateau at Gabel Kalabsha, where its expanse opens to the west and follows the southern margin of the plateau which strikes in an east-west direction and also continues south along Lake Nasser. The elevation of the Nubian plain is about $200 \mathrm{~m}$ above sea level (Issawi 1969). The Sinn El-Kaddab plateau and Nubian plain are dissected by faults, mostly striking east-west, but others north-south, and some southwest-northeast
(Fig. 1b). The faults have strike lengths that extend from a few kilometers to over $200 \mathrm{~km}$. Many of the longer faults are segmented and consist of multiple faults rather than one continuous, uninterrupted fault trace (Woodward-Clyde Consultants 1985). Upon the Nubian plain and at the top of the Sinn El-Kaddab plateau, en echelon basin and dome structures have formed as a result of motion along the faults. Two major faults system can be defined in the study area. The east-west fault trend as Seiyal and Kalabsha faults and the north-south fault system such as Gabel el-Barqa fault, Kurkur fault, Khor el-Ramla fault, Abu Dirwa fault and Gazelle fault. The Kalabsha fault, one of the east-west faults, is approximately $300 \mathrm{~km}$ long and is the most active fault in the study area where the 14 November 1981 earthquake occurred. The Seiyal fault, one of the east-west faults, is approximately $100 \mathrm{~km}$ long with $70 \mathrm{~km}$ located atop the plateau and the remaining $30 \mathrm{~km}$ located on the Nubian plain). The north-south faults are much more localized than the east-west trend faults and run nearly parallel to the main course of Lake Nasser (Issawi 1978, 1982). 


\section{Seismicity and Data Set}

The area under study is located in the southern part of Egypt, and had been considered an aseismic area until the work of Sieberg (1932) who related the damage of Philae and Abu-Simbel temples to earthquake activity near Aswan city. Maamoun (1984) studied the historical seismic activity in Egypt from all available original sources data and disclaimed Siberg's observation. Kebeasy et al. (1987) declared that within $200 \mathrm{~km}$ from Aswan High Dam, there are no earthquakes published in the International Seismological Centre (ISC) bulletin (http://www.isc.ac. uk) during the years from 1920 to 1981. The instrumental era started at Aswan in 1975. From 1975 to early 1982, the earthquake observation system in the Aswan region was operated irregularly. Since June 1982, there has been continuous monitoring of Aswan seismic activity by 13 telemetric short-period seismic stations distributed around the northern part of Lake Nasser. The largest instrumental earthquake that occurred in the target area in the last 38 years was the 14 November 1981 (Kalabsha earthquake) with $M_{\mathrm{s}}$ 5.3 and focal depth $20 \mathrm{~km}$ along the Kalabsha fault. Since then, the seismographic system in Aswan has been updated, where the short-period seismograph was replaced by broadband three-component seismometers and the data is transmitted in digital format via a satellite system. As a result, comprehensive studies have been conducted to investigate the origin of Aswan seismicity. Simpson et al. (1990) noticed that only the Kalabsha earthquake beneath Gabel Marawa and its immediate aftershocks occurred at depth ranging from 15 to $30 \mathrm{~km}$. whereas all other seismic activity in the Aswan region are shallower than $12 \mathrm{~km}$. According to Hassib et al. (2010), deep seismicity follows the typical aftershocks pattern and vanishes with time, while shallow seismic events in the Aswan seismic zone are still triggered. Dominant features of triggered or induced earthquakes are that the seismicity is characterized by swarms, weak and shallow earthquakes concentrated in the same fault patches, with frequent occurrence (e.g., Häring et al. 2008; Cuenot et al. 2008). Aswan seismicity shows repeated cluster microearthquakes with shallow depth and swarm activity, and concentrated along the identified fault segments (e.g., Hassib 1997; Abou
Elenean 2003). The majority of Aswan seismicity appears to be concentrated at the intersection area between the east-west trend and north-south faults system. In addition, this intersection zone is a favorable place for stress accumulation and earthquake generation (Hussein et al. 2013). Good station azimuthal coverage and high-quality data lead to accurate determination of the fault movement mechanism in the target area. Many authors have studied the mechanism of movements along the orthogonal fault systems in the Aswan region and revealed that the dominant movement of Aswan earthquakes is strike slip movement with left-lateral motion along the $\mathrm{N}-\mathrm{S}$ fault system and strike-slip faulting with a right-lateral sense along E-W fault trends (e.g., Hassib 1997; Abou Elenean 2003; Hussein et al. 2013). In light of this, we examined data consisting of 1400 seismic events that took place from 2010 to 2017, a period when the seismic observation system in Egypt was stable in terms of instrumentation and the field stations were almost all equipped by three-component high-quality sensors (Fig. 3a). Figure $2 \mathrm{~b}$ presents the seismicity distribution in and around Egypt from 1901 to 2017, classified by moment magnitude. The data was selected based on having a good signal-to-noise ratio, for earthquakes with good station coverage, and for events recorded at more than four stations. The selected data set is composed of 1200 triggered seismic events located in the Aswan seismic area with local magnitude $0.9 \leq M_{\mathrm{L}} \leq 4$. 6 and depth ranging from 0 to $25 \mathrm{~km}$ (only six events $>3$ ), as shown in Fig. 3a. Forty natural earthquakes are located in the Red Sea seismic zone (five earthquakes with magnitude $\geq 3.6$ ), Triple Junction seismic zone (13 earthquakes with magnitude $\geq 3.5$ ), and Gulf of Aqaba (six earthquakes with magnitude $\geq 3.9$ ), and scattered crustal earthquakes are located in the eastern desert, Nile valley, Cairo-Suez region, and the western desert (10 earthquakes with magnitude $\geq 3.6$ ), as illustrated in Fig. 3b. Spectral inversion is applied to the whole data set mentioned above, while full moment tensor inversion and decomposition are performed for earthquakes with magnitude $>3.0$ which have a good signal-to-noise ratio and have good station azimuthal coverage. 

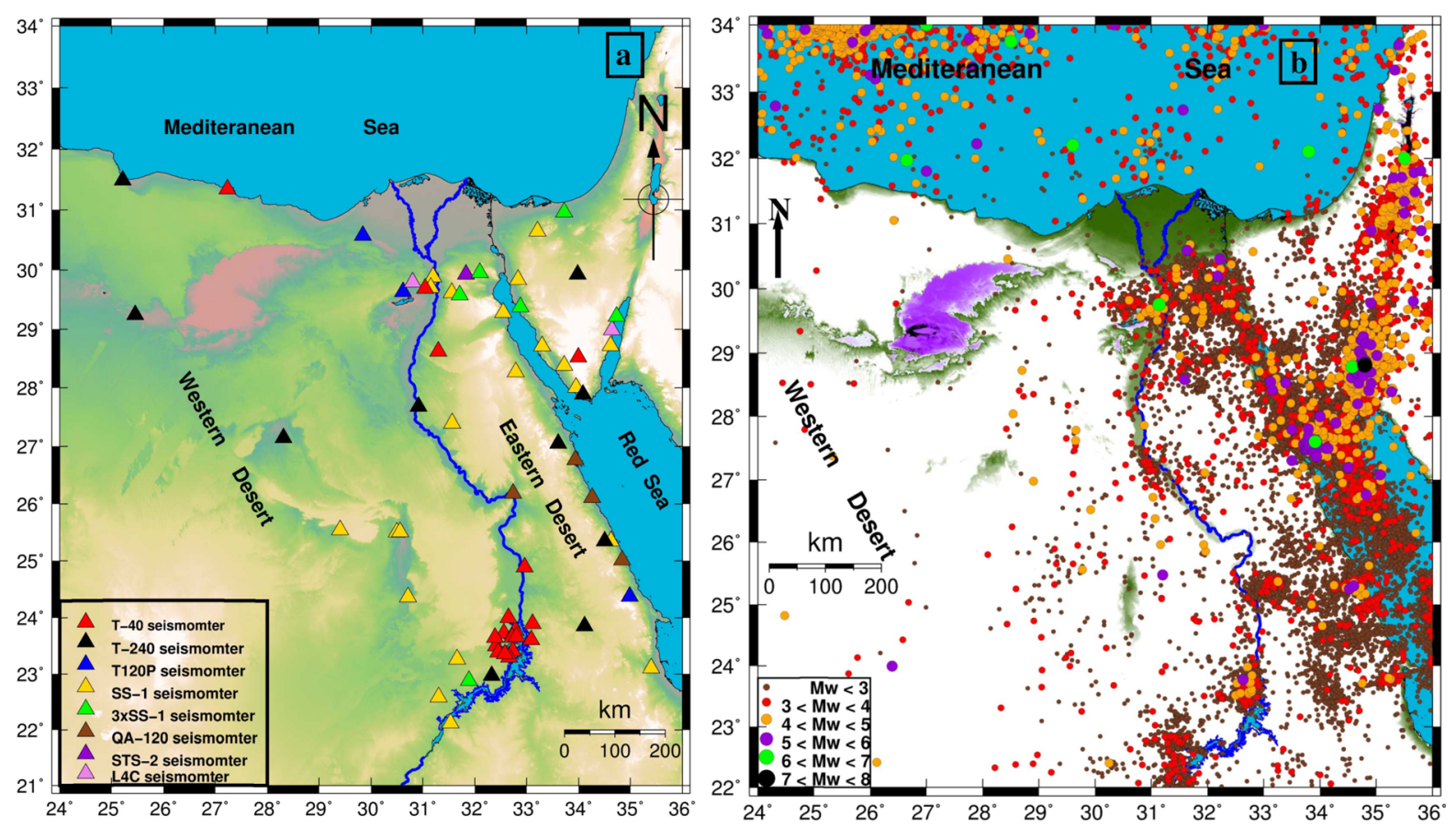

Figure 2

a Geographic distribution of the Egyptian National Seismological Network (ENSN) classified by sensor type (color triangle). b Seismicity map of Egypt classified by magnitude (color circle) from 1901 till 2017
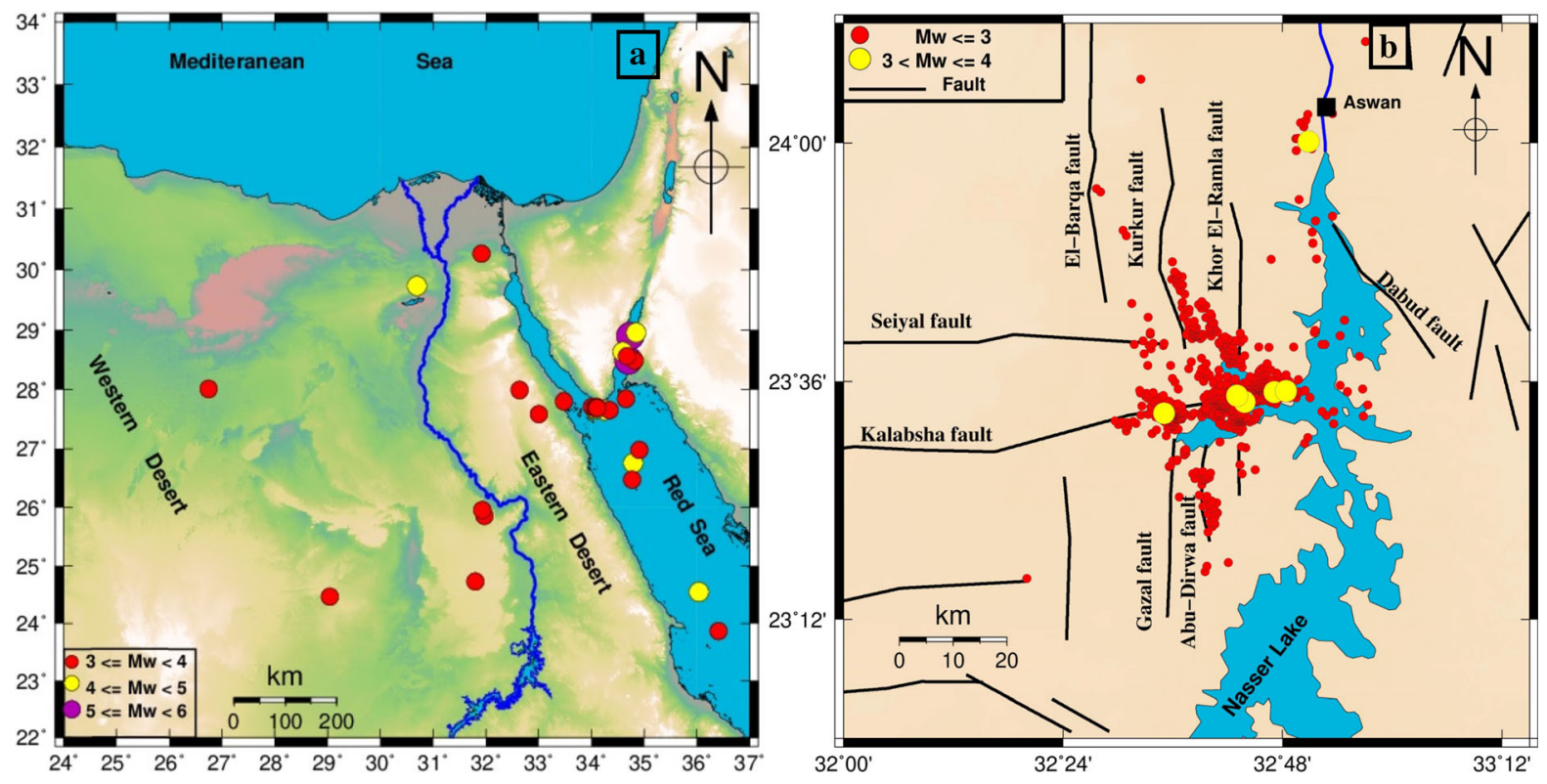

Figure 3

a Selected triggered earthquakes of the Aswan seismic region classified by magnitude (color circle) from 2010 till 2017 . b Selected natural earthquakes of other seismic zones in Egypt from 2010 till 2017 classified by magnitude (color circle) 
Appropriate 1D velocity models are also adopted for the inversion.

\section{Methods}

\subsection{Data Preparation and Green's Function Computation}

The impulse response of the medium between the seismic source and station is known as the elastodynamic Green's function (Jost and Herrmann 1989). The Green's function is a displacement field that depends on the receiver coordinate, source, and velocity structure model (Aki and Richards 2002). In the frame of this work, the Green's function for each epicentral distance and source depth is computed based on the wavenumber integration method (Herrmann and Wang 1985) using a convenient 1D structure model. After preliminary tests, we used the velocity model which gives the lowest variance and best fit to the observed seismic data. For Aswan earthquakes, we used the $1 \mathrm{D}$ velocity structure (Fig. 4a, a*) after Khalil (2004). The 1D structure model adopted by Marzouk (1988) was used for western desert earthquakes (Fig. 4b, b*). For earthquakes that occurred in the Red Sea, Triple Junction, Gulf of Aqaba, eastern desert, and Cairo-Suez seismic zones, we used the 1D structure model (Fig. 4c, c*) adopted by El-Hadidy (1995). Waveform data are recorded by broadband seismic stations of the Egyptian National Seismological Network (ENSN). In addition, a few broadband stations from neighboring networks such as GEOFON (http://www. iris.edu) are included to allow similar station distribution and good azimuthal coverage for seismic events at the edge of the Aqaba Gulf. Seismic data are available in SEED format. Using IRIS RDSEED commands (http://www.iris.edu), the earthquakes data are converted from SEED to SAC format (Fig. 5a). Next, several essential processing steps required before being able to make moment tensor inversion are listed in Fig. 5b-d. The observed seismic data and computed Green's function are filtered within the same frequency band, to decrease the effect of high-frequency scattered waves and longperiod noise before performing moment tensor inversion (Zhang et al. 2016). A frequency band range from 0.02 to $0.2 \mathrm{~Hz}$ was applied for analysis of triggered and natural earthquakes. Both the observed and synthetic seismograms are filtered using a fourpole causal bandpass Butterworth filter.

\subsection{Full Moment Tensor Inversion and Decomposition}

An earthquake's moment tensor is a general concept describing precisely the general type of seismic sources, with shear faulting being just one of them (Udías et al. 2014). Gilbert (1971) related the moment tensor to the total stress drop that occurred at the seismic source region. Backus and Mulcahy (1976, 1976b) reported that the moment tensor describing only the part of the internal stress results from the non-elastic deformation at the source. In general, three approaches are used in moment tensor research. The first one is the amplitude ratio-based technique (e.g., Miller et al. 1998; Hardebeck and Shearer 2003). The second one is the amplitudebased method (e.g., Fojtíková et al. 2010; Godano et al. 2011). The last one is the waveform-based technique (e.g., Dziewonski et al. 1981; Spikin 1986; Zhu and Helmberger 1996; Eyre et al. 2013). In light of this research, we performed moment tensor solutions using full waveforms based on the algorithm in seismology computer programs (Herrmann 2013). For seismic sources having small dimensions with respect to the distance between earthquake source and recording stations (point source assumption) (Vavryčuk 2015), the observed displacement $d$ in direction $n$ at an arbitrary position $x$ and time $t$ are given by the convolution of moment tensor elements with the derivative of Green's function as formulated by Stump and Johnson (1977):

$$
d_{n}=M_{k j}\left[G_{n k, j} * s(t)\right],
$$

where $M_{k j}$ is the elements of the moment tensor $M$, $G_{n k, j}$ denotes the spatial derivative of the Green's function in the $j$ direction, $s(t)$ is the source time function, and the asterisk represents the time convolution. In the frequency domain, assuming the delta function of $s(t)$ (synchronize source), the observed displacement $d_{n}$ is a linear function of the moment 

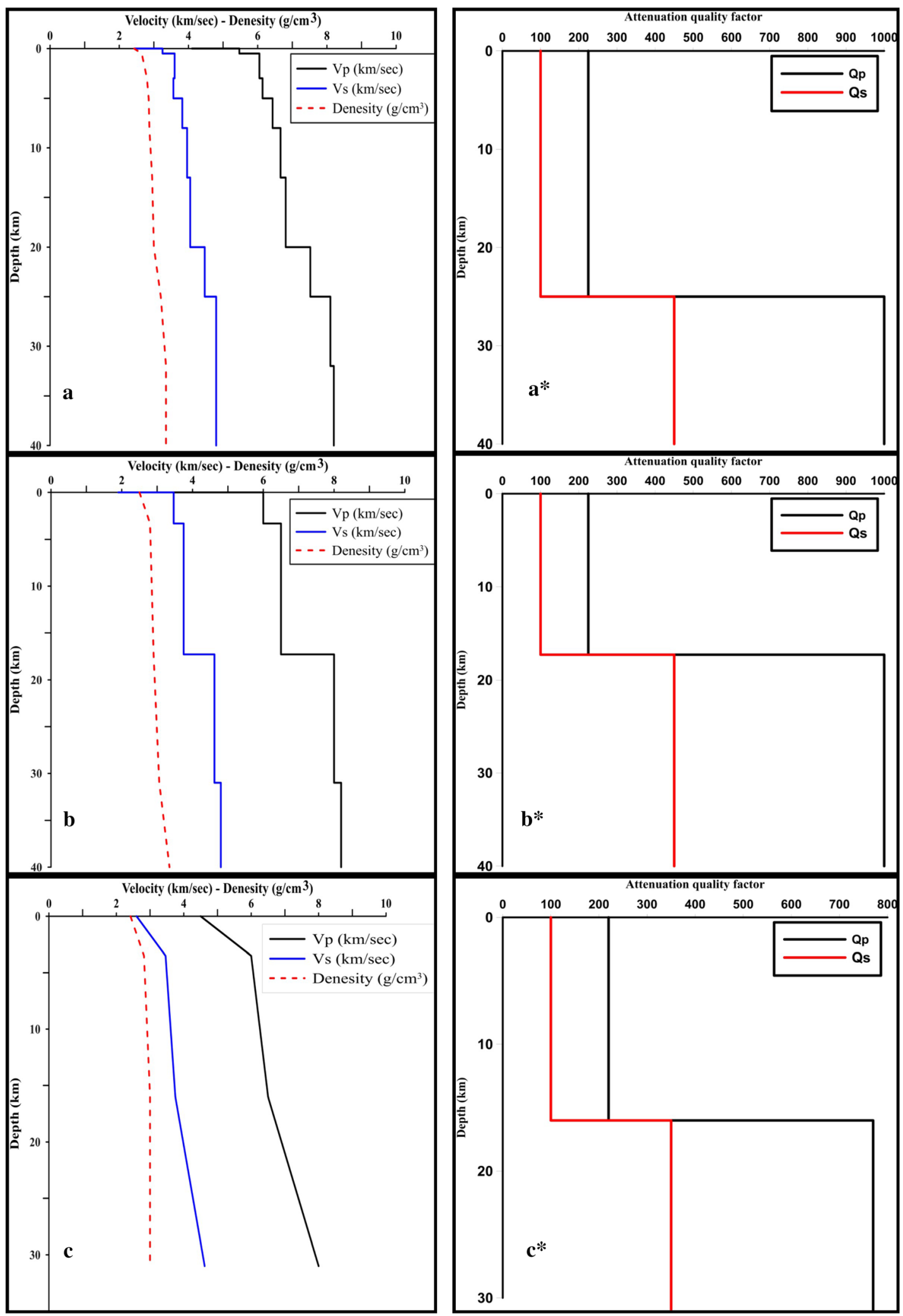
Figure 4

Crustal velocity models adopted in this study for each seismic zone and used in the moment tensor inversion. a, a* After Khalil (2004) for the Aswan region. b, b* After Marzouk (1988) for the western desert region. c, c* After El-Hadidy (1995) for Red Sea, Triple Junction, Gulf of Aqaba, eastern Desert, and Cairo-Suez district regions

tensor elements and the derivative Green's function. Equation (1) can be formulated as

$$
d_{n}(f, x)=M_{k j}(f) G_{n k, j}(f) .
$$

The formulation in Eq. (2) leads to linear inversion in the frequency domain, and can be written in matrix form as follows:

$$
d=G m,
$$

where $d$ is the observed displacement spectra, $G$ is a matrix containing the Green's functions computed using an appropriate structure model, and $m$ is a vector with six components of the moment tensor. The linear inversion approach in Eq. (3) is solved using a generalized least-square technique (Jost and Herrmann 1989). After the raw data are processed and the Green's function for each epicentral distance and each seismic source depth are computed, the moment tensor inversion is performed at a range of hypocenter depths to achieve the best fit between the calculated and observed waveforms, selected based on goodness of fitting. The variance reduction can be formulated as in Zhang et al. (2016):

$$
R=\left[\frac{1-(O-C) \cdot(O-C)}{O^{2}}\right] \times 100,
$$

where $O$ is the observed waveform, and $C$ is the calculated waveform.

The best solutions for the source mechanism, source depth, and moment magnitude corresponding to the lowest normalized variance are taken as the best and final result for the studied earthquakes. After the inversion is processed for the best double-couple (DC), the complete moment tensor is diagonalized and decomposed into isotropic and deviatoric components.

$$
\begin{aligned}
m=\frac{1}{3} & {\left[\begin{array}{ccc}
\operatorname{tr}(M) & 0 & 0 \\
0 & \operatorname{tr}(M) & 0 \\
0 & 0 & \operatorname{tr}(M)
\end{array}\right] } \\
+ & {\left[\begin{array}{ccc}
m_{1}^{*} & 0 & 0 \\
0 & m_{2}^{*} & 0 \\
0 & 0 & m_{3}^{*}
\end{array}\right], }
\end{aligned}
$$

where $m$ in the left part of Eq. (5) is the diagonalized moment tensor. The first term in the right part represents the volume change in the seismic source (isotropic part), and the second part denotes the deviatoric part of the moment tensor.

Many decomposition methods are adopted for the deviatoric part of the moment tensor in literature, including three vector dipoles, major and minor DC, and three compensated vector dipoles. In this work, we applied the DC and compensated linear vector dipole (CLVD) decomposition approach which is widely used in the source studies. Assuming that $\left|m_{3}^{*}\right| \geq\left|m_{2}^{*}\right| \geq\left|m_{1}^{*}\right|$, and that the same principal stresses produce DC and CLVD radiation, we can decomposed the deviatoric part in Eq. (5) as in Knopoff and Randall (1970) and Fitch et al. (1980):

$$
\begin{aligned}
M^{\mathrm{DEV}}= & (1-2|\varepsilon|) m_{3}^{*}\left[\begin{array}{ccc}
0 & 0 & 0 \\
0 & -1 & 0 \\
0 & 0 & 1
\end{array}\right] \\
& +|\varepsilon| m_{3}^{*}\left[\begin{array}{ccc}
-1 & 0 & 0 \\
0 & -1 & 0 \\
0 & 0 & 2
\end{array}\right]
\end{aligned}
$$

where $m_{1}^{*}, m_{2}^{*}$, and $m_{3}^{*}$ are the deviatoric principal moment for the null, pressure, and tension axis, respectively. The DC component is represented by the first right part in Eq. (6), and the CLVD part is represented by the second term. $m_{3}^{*}$ is the deviatoric part with the largest absolute eigenvalue. The parameter $\varepsilon$ is a measure of the departure of the seismic source from the shear faulting model (Dziewonski et al. 1981) and is defined as:

$$
\varepsilon=\left|\frac{m_{\min }^{*}}{m_{\max }^{*}}\right|,
$$

where $m_{\min }^{*}$ and $m_{\max }^{*}$ are the smallest and largest absolute value of the eigenvalues, respectively. $\varepsilon$ is equal zero for a pure DC source and is equal to 0.5 for a pure CLVD source. The percentage of the DC and non-DC (CLVD) constituting the deviatoric 

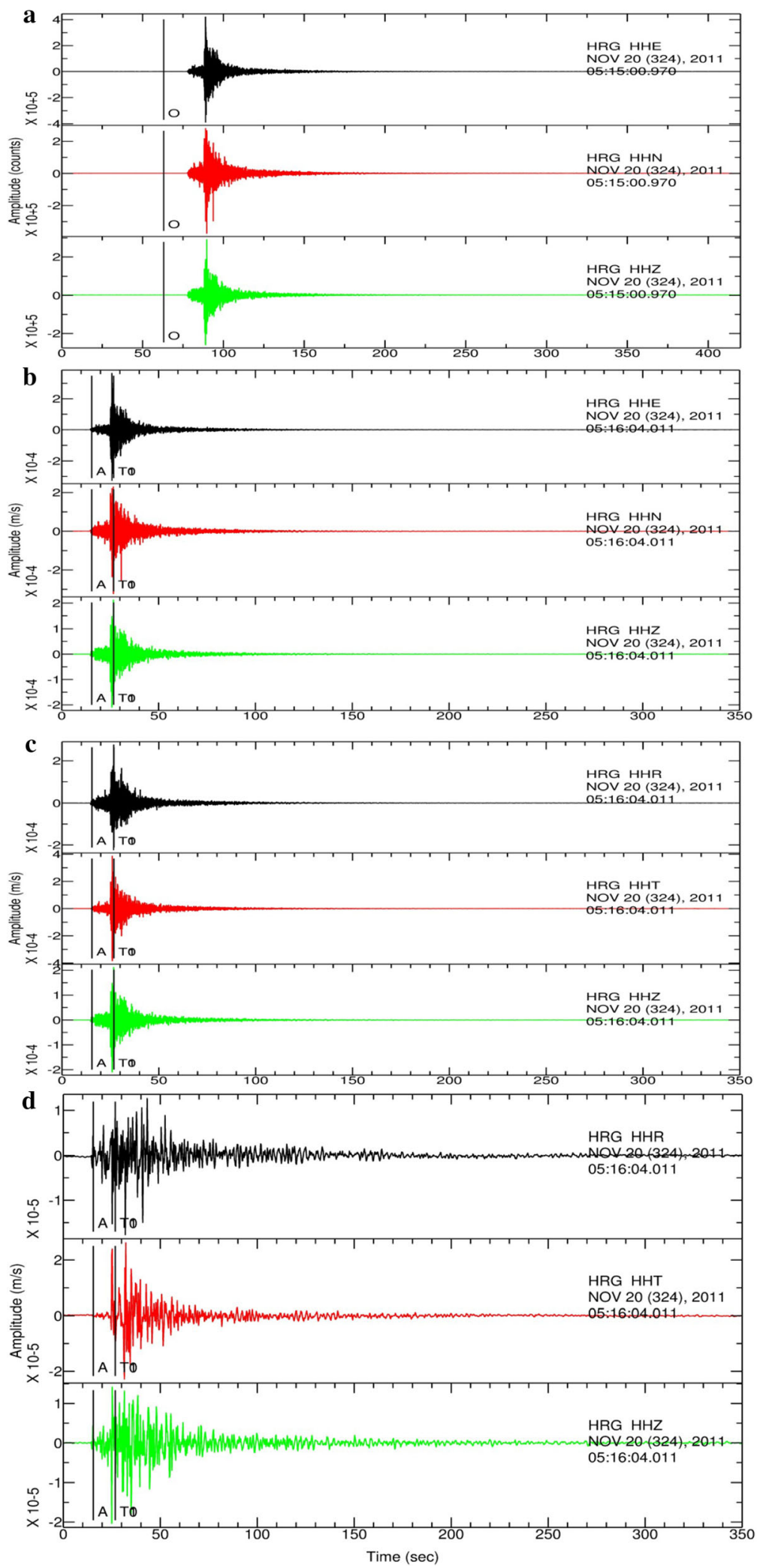
Figure 5

Example of the preliminary data processing steps of the 20 November $2011\left(M_{\mathrm{L}} 4.2\right)$ earthquake at 05:16 UTC time. Raw data in counts $/ \mathrm{m} / \mathrm{s}$ reformatting from SEED to SAC format (a). The instrument response is removed by deconvolution of the response for each sensor and the traces had the physical units of $\mathrm{m} / \mathrm{s}(\mathbf{b})$. The horizontal components EW and NS are rotated to traverse and radial (c). Finally, velocity data after applying a low-pass filter for synthetic and observed seismograms (d)

component of the moment tensor is calculated as follows:

$$
\begin{gathered}
\mathrm{DC}=200 \times \varepsilon, \\
\mathrm{CLVD}=(1-2 \varepsilon) \times 100 .
\end{gathered}
$$

\subsection{Generalized Inversion Technique (GIT) Using a Reference Site}

The GIT constrained by a reference station is used to isolate the displacement source spectrum from the observed seismogram following the approach described by Iwata and Irikura (1988). They assumed that each observed spectra $d_{i j}$ from the source $i$ and receiver $j$ in the frequency domain is a convolution of the source effect $e_{i}(f)$, site effect $s_{j}(f)$, and path attenuation $p_{i j}(f)$, expressed as

$$
d_{i j}(f)=e_{i}(f) s_{j}(f) P_{i j}(f) .
$$

The above simultaneous linear equation is numerically solved using the iterative least square technique. To avoid the trade-off between the site and source results, many authors use a reference site and set the amplification equal to 2 due to the free surface effect at this site. We used Gabel Marawa station (GMR), located in the Aswan region and belonging to the ENSN. The GMR site is composed of compact sandstone where the amplitude ratio is almost equal units, with no obvious predominant frequency at this station (Saadalla et al. 2019). Before performing the inversion, some preliminary steps are essential to condition the observed data. First, data are converted from the SEED archive to a SAC format using RDSEED software (http://www.iris. edu). The arrival times of $\mathrm{P}$ and $\mathrm{S}$ waves are manually picked using the plot picking command of Seismic Analysis Code (SAC) (Goldstein and Snoke 2005). The lengths of time windows are set to $1.28 \mathrm{~s}$ and $2.56 \mathrm{~s}$ for $\mathrm{P}$ and $\mathrm{S}$ waves, respectively. Also, the window length of pre-event noise starts $0.5 \mathrm{~s}$ before the picked P-phase arrival. The mean and linear trend are removed. Zero padding, a Parzen window of $5.0 \mathrm{~Hz}$, and the data point are tapered with a $1 \%$ taper window. The spectra is then calculated using fast Fourier transform (FFT) analysis. The instrument response is corrected during the processing steps using the polezero $\mathrm{s}$ file for each station. Finally, data with an acceptable signal-to-noise ratio (SNR) over the frequency range from $0.8 \mathrm{~Hz}$ to $50 \mathrm{~Hz}$ are used in the inversion processes.

The abovementioned inversion technique enables separation of the displacement spectra from the recorded seismogram. Next, the displacement source term is processed based on Brune's (1970) model for small seismic events assuming circular faulting as follows:

$$
d_{i}(f)=\frac{\Omega_{0}}{1+\left(f / f_{\mathrm{c}}\right)},
$$

where $\Omega_{0}$ is the flat level of the amplitude spectra, $f$ is the frequency, and $f_{c}$ is the corner frequency. The scalar seismic moment can be derived from $\mathrm{P}$ - and $\mathrm{S}$ wave source spectra following Brune's (1970) relation as

$$
M 0=\frac{4 \pi \rho v^{3}}{F \times R_{\theta \varphi} \times G(r, h)} \Omega_{0},
$$

where $\rho$ is the density, $v$ is the seismic wave velocity, $F$ is the effect of the free surface, $R_{\theta \varphi}$ is the radiation pattern, and $G(r, h)$ is the geometrical spreading effect. The values of density and $\mathrm{P}$ - and S-wave velocities are taken from El-Hadidy's (1995) velocity model. For radiation pattern correction, we used 0.52 and 0.63 for P- and S-waves, respectively (Aki and Richards 2002). Based on Madariaga's (1976) dynamic calculation, the radius of the rupture area can be given as follows:

$$
r=\frac{k \beta}{f_{c}},
$$

where $r$ is the fault radius, and $k$ is a constant that depends on the specific theoretical model. Assuming that the rupture velocity is $90 \%$ of the shear wave velocity, Madariaga's (1976) calculation reveals that $k$ is 0.32 and 0.21 for $\mathrm{P}$ - and $\mathrm{S}$-waves, respectively. 
The corner frequency was calculated for each source spectra following Andrews (1986). Finally, the static stress drop was estimated using the computed seismic moment and source radius following Eshelby's (1957) formulation:

$$
\Delta \sigma=\frac{7}{16}\left(\frac{M_{\mathrm{o}}}{r^{3}}\right)
$$

\section{Moment Tensor Results and Discussion}

The reliability of our result of the full moment tensor solution and decomposition is evaluated based on the waveform fitting between observed and predicted seismograms, the SNR, and arrival time shift. Our findings are subsequently integrated and compared with previous works and results.

\subsection{Aswan Seismic Zone}

The best solution of double-couple, seismic moment, moment magnitude, focal depth, and variance (goodness of fitting) for six triggered earthquakes that occurred in the Aswan seismic zone are registered in Table 2. Figure 6 shows an example of the best focal mechanism solution (a) and depthfitting (b) results for one triggered earthquake (7 November 2010) in the Aswan region. The focal mechanism for all six earthquakes indicates a strikeslip movement as the dominant characteristic of Aswan seismic activity (Fig. 7a). Earthquake nos. 1, 2, 3, 4, and 6 have strike-slip movement with nodal planes oriented NE-SW and NNW-SSE. Earthquake no. 5 took place in the southern part of Lake Nasser with a strike-slip mechanism, and its planes are oriented NNE-SSW and E-W. In general, the obtained results of focal mechanism are in good

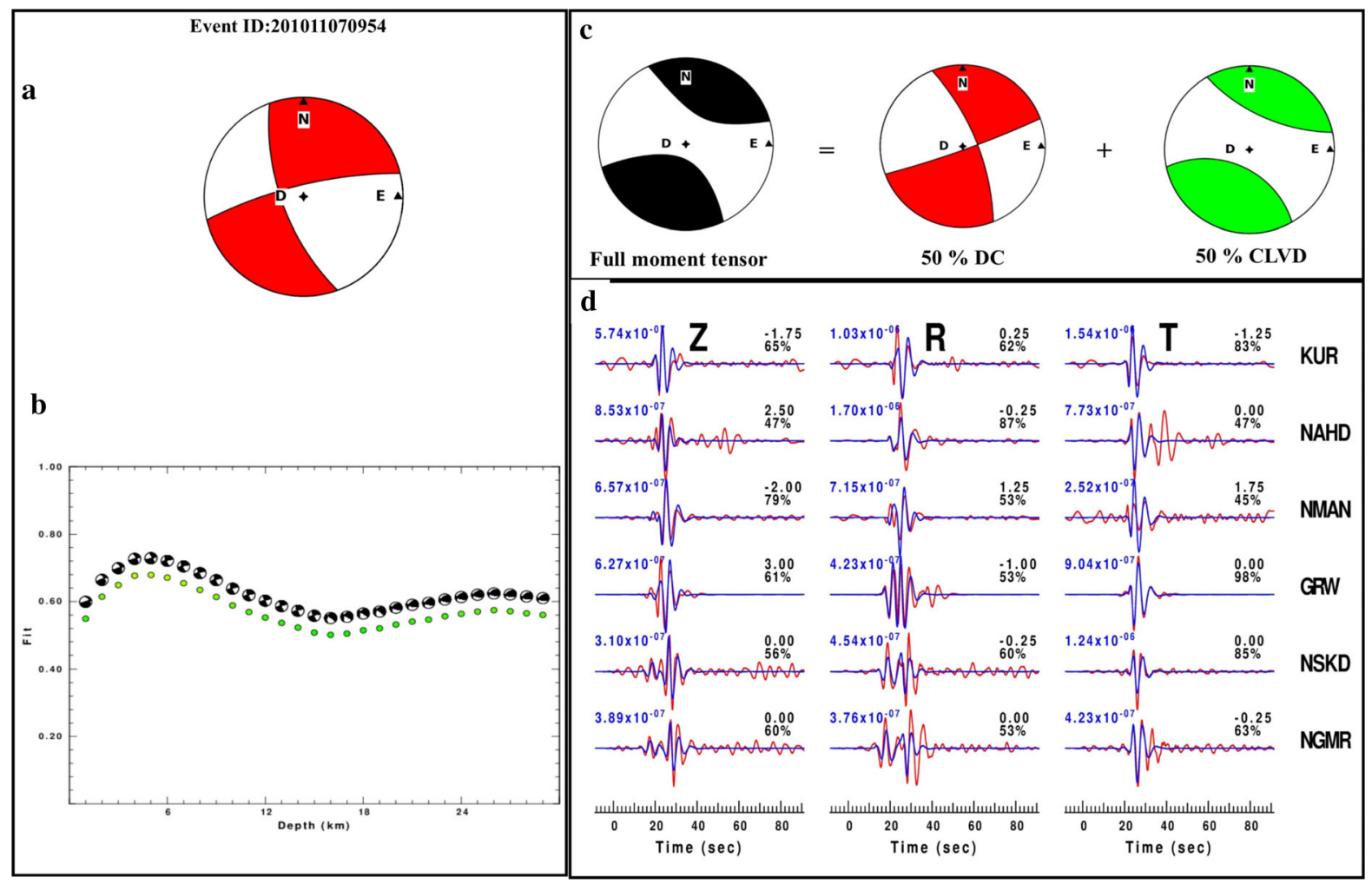

Figure 6

Full moment tensor solution and decomposition example of the 7 November $2010\left(M_{L} 4.6\right)$ earthquake that occurred in the Aswan seismic zone. a Best solution for DC, b depth fitting for best solution DC, $\mathbf{c}$ full moment tensor decomposition, and $\mathbf{d}$ waveform fitting between observed (red traces) and synthetic (blue traces) seismogram 


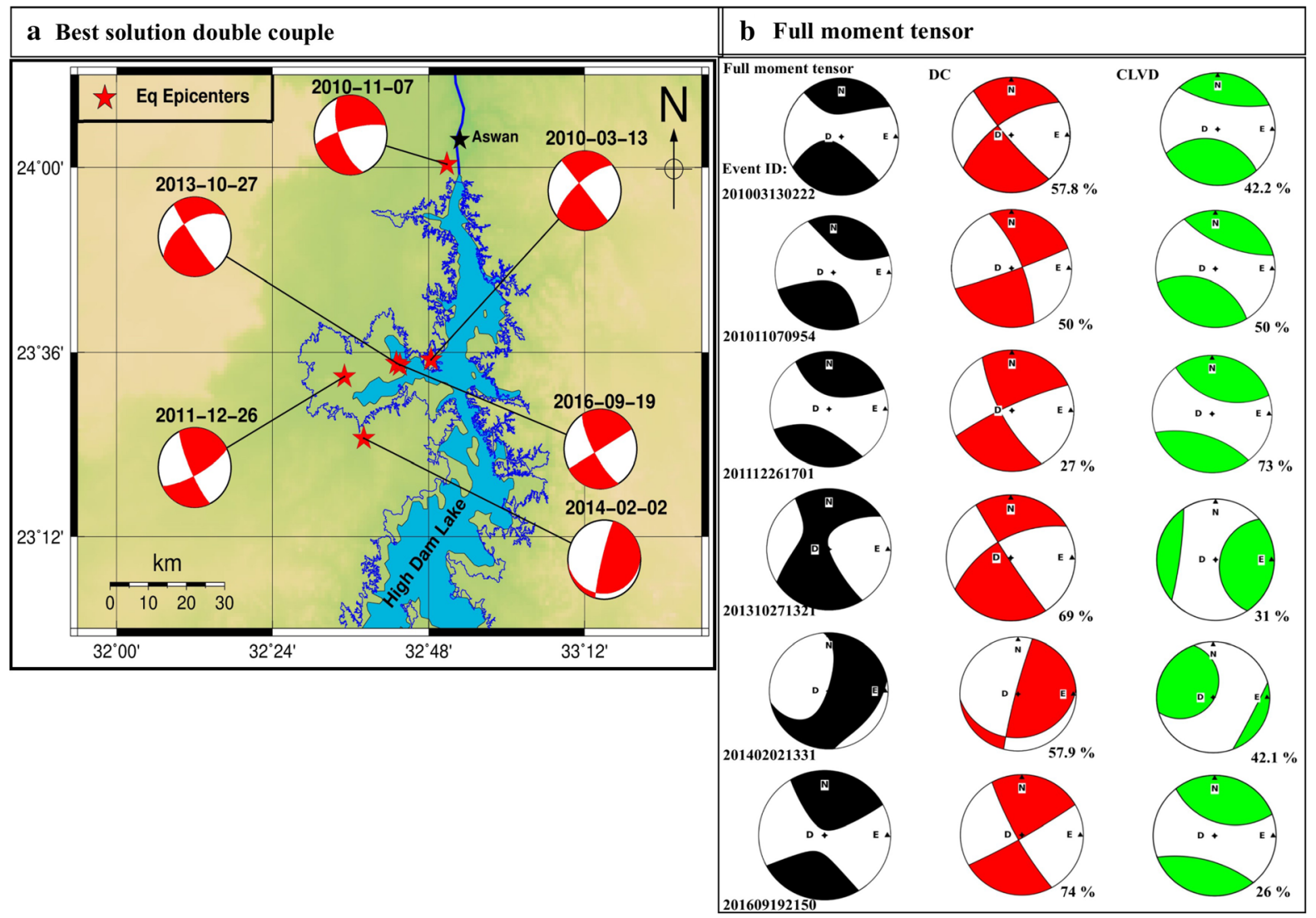

Figure 7

a The best solution double-couple distribution in the Aswan seismic zone. b The full moment tensor solution with compressional field colored by black and the percentage of its decomposing components, DC (shaded in red) and CLVD (shaded in green)

agreement with the surface trace of the Kalabsha fault plane (the main active fault in the Aswan area) and consistent with previous studies (e.g., Badreldin et al. 2019; Hosny et al. 2014; Hussein et al. 2013; Hassib et al. 2010; Abou Elenean 2003). The obtained depth for all events ranges from 3 to $10 \mathrm{~km}$, except for the most recent earthquake that took place in 19 September 2016 which has a depth of $25 \mathrm{~km}$. The obtained moment magnitude for most of the events under study are lower than the assigned local magnitude in the published catalog. For example, the moment magnitude of spillway earthquakes ( 7 November 2010) is 3.4 compared with a published local magnitude of 4.6 (Table 1). In order to extract further information about Aswan source processes, full moment tensor inversions are applied, then decomposed into two parts, DC and CLVD, which is a widely used decomposition following Jost and Herrmann (1989). Figure 7b represents the full waveform moment tensor solutions and their decomposed components in percent for each of the six seismic events. The Mopad tool (Krieger and Heiman 2012) is used to plot the full moment tensor solution, CLVD and DC components. The obtained complete focal mechanism for Aswan earthquakes is characterized by a non-negligible non-DC component range from 31 to $74 \%$ with an average value of $44 \%$ and DC component range from 26 to $69 \%$ with an average value of $56 \%$ (Table 2 and Fig. $7 \mathrm{~b}$ ). The only event with a comparable DC value (74\%) is the deepest one with a focal depth of $25 \mathrm{~km}$ for the earthquake that occurred on 19 September 2016 at 21:54 UTC time. In general, the fitting between synthetic and observed seismograms for all seismic 
Table 1

Initial source parameters of the selected data of the Aswan seismic zone as reported in the ENSN catalog

\begin{tabular}{|c|c|c|c|c|c|c|}
\hline $\begin{array}{l}\text { Event } \\
\text { no. }\end{array}$ & $\begin{array}{l}\text { Event } \\
\text { date } \\
\text { (YYYY/ } \\
\text { MM/ } \\
\text { DD) }\end{array}$ & $\begin{array}{l}\text { Time } \\
\text { (hh:mm:ss) } \\
\text { UTC }\end{array}$ & Latitude & Longitude & $\begin{array}{l}\text { Depth } \\
(\mathrm{km})\end{array}$ & $M_{\mathrm{L}}$ \\
\hline 1 & $\begin{array}{c}2010 / 03 / \\
13\end{array}$ & $02: 22: 16$ & 23.5840 & 32.8060 & 4 & 3.8 \\
\hline 2 & $\begin{array}{c}2010 / 11 / \\
07\end{array}$ & 09:54:34 & 24.0070 & 32.8472 & 21 & 4.6 \\
\hline 3 & $\begin{array}{l}2011 / 12 / \\
26\end{array}$ & $17: 01: 25$ & 23.5470 & 32.5840 & 11.6 & 4.2 \\
\hline 4 & $\begin{array}{c}2013 / 10 / \\
27\end{array}$ & $13: 21: 42$ & 23.5718 & 32.7259 & 3.5 & 3.8 \\
\hline 5 & $\begin{array}{c}2014 / 02 / \\
02\end{array}$ & $13: 31: 25$ & 23.4133 & 32.6340 & 3 & 3.7 \\
\hline 6 & $\begin{array}{c}2016 / 09 / \\
19\end{array}$ & $21: 50: 54$ & 23.5760 & 32.7170 & 22 & 3.5 \\
\hline
\end{tabular}

ENSN Egyptian National Seismic Network, $M_{L}$ local magnitude

events exceeded $70 \%$, the arrival time shift is less than $5 \mathrm{~s} \mathrm{(Fig.} \mathrm{8),} \mathrm{and} \mathrm{the} \mathrm{SNR} \mathrm{is} \mathrm{acceptable} \mathrm{(Fig.} \mathrm{9).}$ Finally, the mis-modelling mostly ranges from 20 to $30 \%$, with excellent azimuthal coverage, high-quality data, and high SNR, suggesting that the relatively non-negligible non-DC component observed for earthquakes in the Aswan region cannot be regarded purely as artifact. Figure $6 \mathrm{c}$, d shows the full moment tensor decomposition example (c) and waveform fitting (d) for earthquakes that occurred on 7 November 2010 at 09:54 UTC time. The existence of noticeable CLVD components with positive values

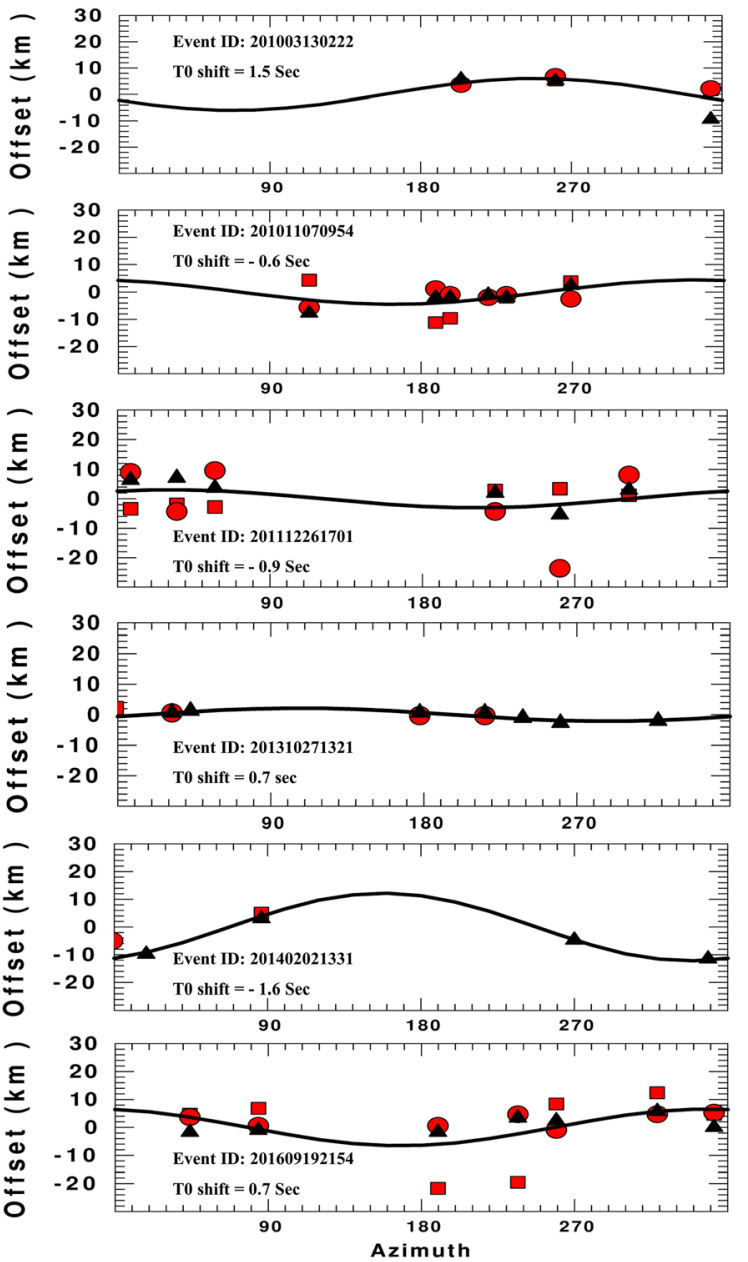

Figure 8

Time shifts between the predicted and observed traces for each seismograph component; vertical ray (red square), radial ray (red circle), and traverse ray (black triangle)

Table 2

Best solution double-couple and moment tensor decomposition for selected Aswan earthquakes

Event no. Best solution double-couple

Decomposition

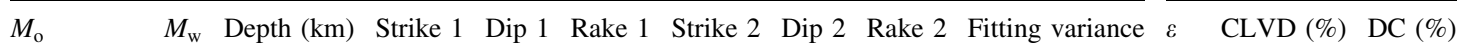
(dyn-cm)

\begin{tabular}{|c|c|c|c|c|c|c|c|c|c|c|c|c|}
\hline 1 & $1.53 \mathrm{E}+21$ & 3.4 & 8 & 140 & 90 & -20 & 230 & 70 & -180 & 0.2 & $0.2 \quad 42.2$ & 57.8 \\
\hline 2 & $9.77 \mathrm{E}+20$ & 3.3 & 5 & 256 & 76 & -154 & 160 & 65 & -15 & 0.3 & $0.2 \quad 50.0$ & 50.0 \\
\hline 3 & $1.78 \mathrm{E}+22$ & 4.1 & 10 & 155 & 80 & 15 & 62 & 75 & 170 & 0.3 & $0.4 \quad 73.0$ & 27.0 \\
\hline 4 & $2.37 \mathrm{E}+20$ & 2.9 & 3 & 145 & 85 & -35 & 238 & 55 & -174 & 0.2 & $0.2 \quad 30.4$ & 69.6 \\
\hline 5 & $3.89 \mathrm{E}+21$ & 3.7 & 3 & 194 & 85 & 76 & 85 & 15 & 160 & 0.4 & $0.2 \quad 42.1$ & 57.9 \\
\hline 6 & $2.02 \mathrm{E}+21$ & 3.5 & 25 & 150 & 75 & 0 & 240 & 90 & -165 & 0.3 & $0.1 \quad 26.1$ & 73.9 \\
\hline
\end{tabular}

$M_{\mathrm{o}}$ Seismic moment in dyn-cm, $M_{\mathrm{w}}$ moment magnitude, $\varepsilon$ measure of the deviation of seismic sources from double-couple mechanism, $C L V D$ compensated linear vector dipole component, $D C$ double-couple component 


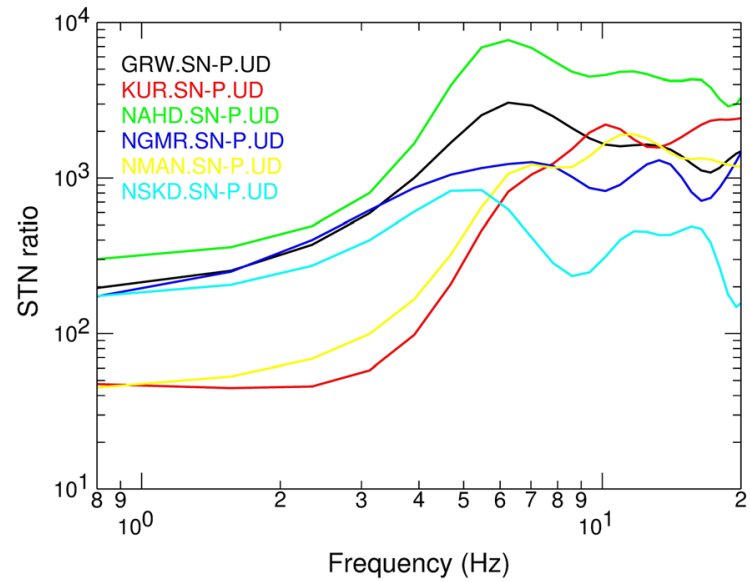

Figure 9

Example of signal-to-noise ratio (SNR) at each station recorded for the 7 November 2010 earthquakes in Aswan region

suggests that a tensile faulting mechanism is a dominant feature of Aswan seismic activity. Tensile rupture is dominated by discontinuous displacement which is not parallel to the surface of the fault plane and gives raise to a non-DC component (Vavryčuk 2014, 2015). Under high pressure of pore fluid, tensile faulting are permissible. In addition, the compressive lithostatic stress acting against opening of crack at depth in the earth can be cancelled out due to the effect of fluid pressure (Julian et al. 1998). Results of previous studies on the nature and characteristics of Aswan seismicity indicated that shallow and deep earthquakes are controlled by the high pressure of pore fluid along the existing complex orthogonal faults in the study area and have swarm character (e.g., Telesca et al. 2017; Hussein et al. 2013; Gahalaut and Hassoup 2012; Hassib et al. 2010; Kebeasy and Gharib 1991; Simpson et al. 1986). Integration of our results with previous findings indicates that the assumption of tensile faulting due to high pore fluid pressure may reasonably explains the non-negligible CLVD components.

\subsection{Gulf of Aqaba Seismic Zone}

The Gulf of Aqaba represents the southern extension of the Dead Sea Transform (DST) fault, and is the most active seismic area in Egypt which poses considerable seismic hazard to the neighboring countries. Its tectonic activity is mostly attributed to the sea floor rifting of the Red Sea and the relative motion between Africa, Arabia, and Eurasia plates (Makris and Henke 1992; Fairhead and Girdler 1970). The dominant structure of the Gulf of Aqaba is leftlateral strike-slip with minor normal movement with main fault trends N-S to NNE-SSW and NW-SE (Abdel-Fattah et al. 1997; Pinar and Türkelli 1997; Ben-Avraham 1985). The seismicity pattern of the Aqaba Gulf occurs as isolated patches and is characterized by foreshock-mainshock-aftershock and mainshock-aftershock sequences. Six seismic events with magnitude and depth ranging from 3.9 to 5.4 and 14 to $25 \mathrm{~km}$, respectively, during the studied period (Table 3) were selected for the implementation of full moment tensor inversion. The best double-couple solutions indicated strike-slip movement with minor normal faulting (Fig. 10a). Our results are consistent with other recent studies of Aqaba Gulf earthquakes (Abd el-aal et al. 2019; Abd el-aal and Badreldin 2016) and international seismological centers such as the USGS (www.usgs.gov), GCMT (www.globalcmt.org), and GFZ (www.gfzpotsdam.de). The obtained moment magnitude for most of the events are lower than the published local magnitude, as shown in Table 4. Other source

Table 3

Initial hypocenter parameters of Gulf of Aqaba earthquakes as published in the ENSN catalog

\begin{tabular}{|c|c|c|c|c|c|c|}
\hline Event no. & Event date (YYYY/MM/DD) & Time (hh:mm:ss) UTC & Latitude & Longitude & Depth $(\mathrm{km})$ & $M_{\mathrm{L}}$ \\
\hline 1 & $2010 / 07 / 15$ & $11: 25: 54$ & 28.9555 & 34.8508 & 14.2 & 4.2 \\
\hline 2 & $2015 / 06 / 27$ & $15: 34: 02$ & 28.4507 & 34.7848 & 25.0 & 5.4 \\
\hline 3 & $2016 / 05 / 16$ & $01: 45: 58$ & 28.4507 & 34.7163 & 15.0 & 5.4 \\
\hline 4 & $2016 / 08 / 13$ & 02:06:14 & 28.4921 & 34.8190 & 19.1 & 3.9 \\
\hline 5 & $2016 / 11 / 29$ & $17: 01: 16$ & 28.6322 & 34.5956 & 22.0 & 4.4 \\
\hline 6 & $2016 / 12 / 27$ & 01:49:02 & 28.5602 & 34.6751 & 17.1 & 4.1 \\
\hline
\end{tabular}




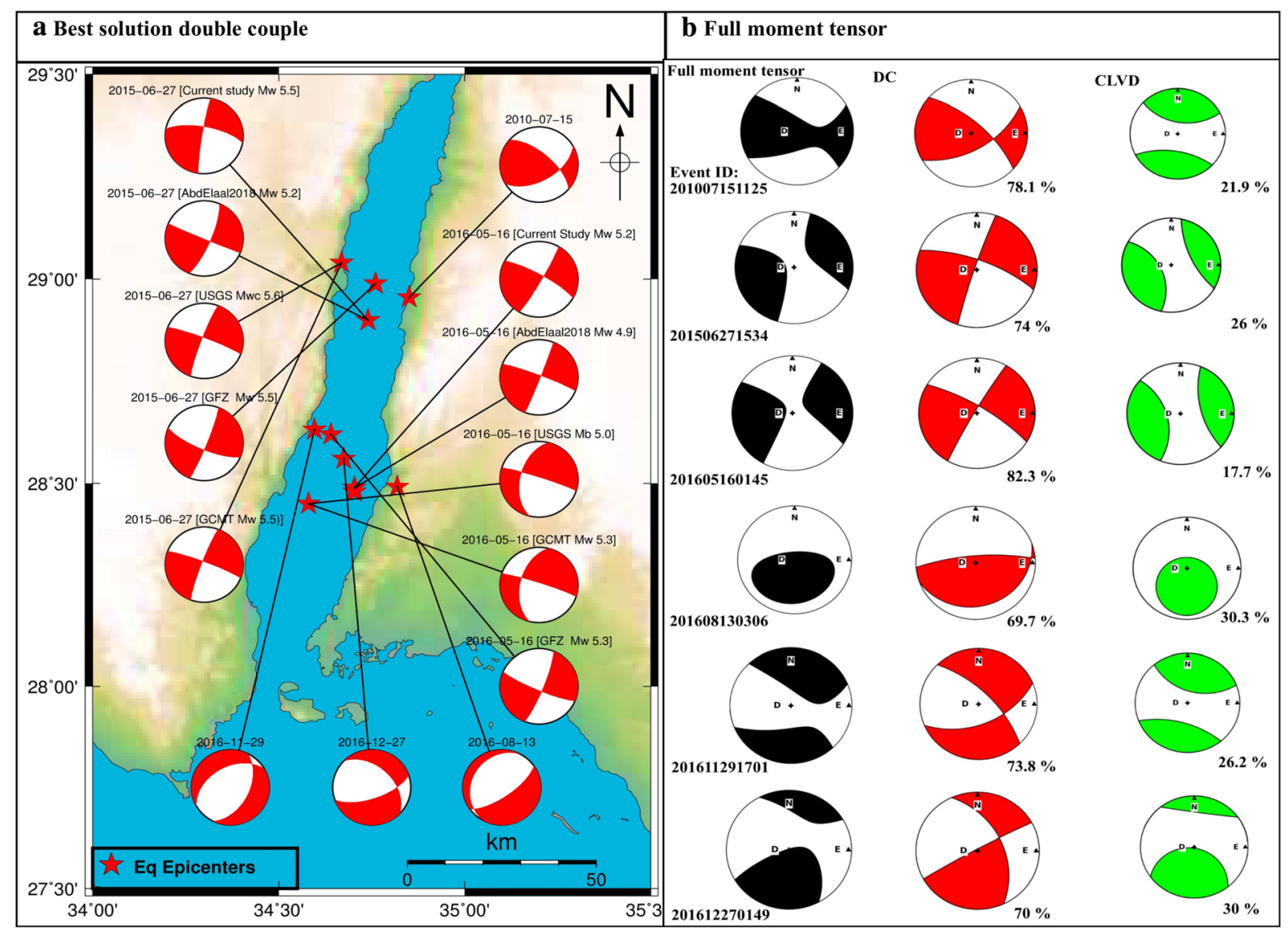

Figure 10

a Distribution of the best fault plane solution double-couple in the Gulf of Aqaba seismic zone. b The percentage of the full moment tensor parts and their lower hemisphere projection (from left to right), with the full mechanism with compressional field colored by black, DC shaded in red, and CLVD shaded in green

Table 4

Best fault plane solution based on full moment tensor inversion and decomposition for Gulf of Aqaba earthquakes

\begin{tabular}{|c|c|c|c|c|c|c|c|c|c|c|c|c|c|}
\hline \multirow[t]{2}{*}{ Event no. } & \multicolumn{10}{|c|}{ Best solution double-couple } & \multicolumn{3}{|c|}{ Decomposition } \\
\hline & $M_{\mathrm{o}}(\mathrm{dyn}-\mathrm{cm})$ & $M_{\mathrm{w}}$ & Depth $(\mathrm{km})$ & Strike 1 & Dip 1 & Rake 1 & Strike 2 & Dip 2 & Rake 2 & Fitting variance & $\varepsilon$ & CLVD $(\%)$ & $\mathrm{DC}(\%)$ \\
\hline 1 & $1.45 \mathrm{E}+22$ & 4.0 & 26 & 10 & 60 & -55 & 136 & 45 & -135 & 0.2 & 0.1 & 21.9 & 78.1 \\
\hline 2 & $2.16 \mathrm{E}+24$ & 5.5 & 25 & 189.3 & 85.3 & -20 & 290 & 70 & -175 & 0.3 & 0.1 & 26.0 & 74.0 \\
\hline 3 & $6.92 \mathrm{E}+23$ & 5.2 & 21 & 30 & 85 & 10 & 299 & 80 & 175 & 0.2 & 0.1 & 17.7 & 82.3 \\
\hline 4 & $2.66 \mathrm{E}+21$ & 3.6 & 20 & 55 & 70 & -80 & 208 & 22 & -116 & 0.2 & 0.2 & 30.3 & 69.7 \\
\hline 5 & $1.07 \mathrm{E}+23$ & 4.6 & 23 & 240 & 45 & -65 & 27 & 50 & -113 & 0.2 & 0.1 & 26.2 & 73.8 \\
\hline 6 & $2.85 \mathrm{E}+21$ & 3.6 & 15 & 71 & 66 & -129 & 315 & 45 & -35 & 0.4 & 0.2 & 30.3 & 69.7 \\
\hline
\end{tabular}




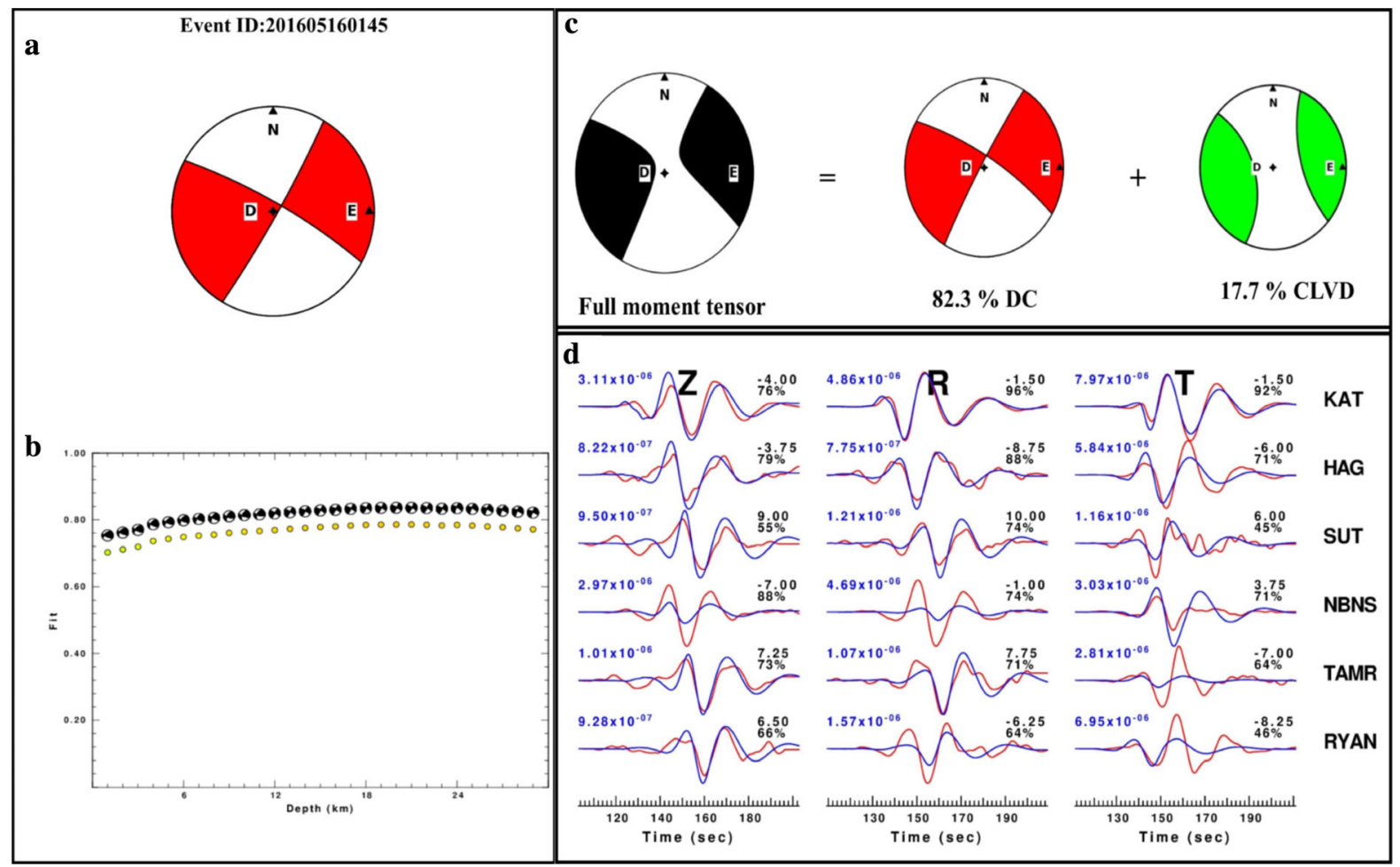

Figure 11

Example of the complete moment tensor and decomposition of the 16 May $2016\left(M_{\mathrm{L}} 5.4\right)$ earthquake that occurred in the Aqaba Gulf seismic zone. a Best solution DC, b depth fitting, $\mathbf{c}$ full moment tensor and the percentage of its decomposed parts, $\mathbf{d}$ waveform fitting between observed (red traces) and synthetic (blue traces) seismograms

parameters for some of the events, particularly the focal depths, show considerable differences from the assigned catalog (Table 3). For example, the estimated depth for the earthquake of 16 May 2016 is $21 \mathrm{~km}$, compared with a reported depth of $15 \mathrm{~km}$ by the published NRIAG catalog. However, international earthquakes centers catalog such as USGS (www.usgs.gov) report that the event depth is $26 \mathrm{~km}$. Figure 11a, b shows an example of the best solution focal mechanism (a) and depth fitting result (b) of the 16 May 2016 earthquake at 01:45 UTC. Full waveform decomposition and moment tensor inversion of Gulf of Aqaba earthquakes is dominated by a high DC component (70-82\%) with an average value of $75 \%$ associated with a low CLVD component $(18-30 \%)$ with an average value of $25 \%$, as in Fig. 10b and listed in Table 4. Figure 11c, d shows an example of the full moment tensor solution and decomposition (c) and waveform fitting (d) for earthquakes that occurred on 16 May 2016 at 01:45 UTC time. In summary, the goodness of fitting between the calculated and observed waveforms exceeded $80 \%$ with a time shift less than $5 \mathrm{~s}$, and data with high SNR indicated that our results for the Gulf of Aqaba seismic zone are accurate and robust. The obtained DC values for all earthquakes are an indication that the Gulf of Aqaba faulting follows the shear faulting assumption and that the observed minor percentage of non-DC components refers to the complex rupture area in this zone.

\subsection{Triple Junction Seismic Zone}

Triple Junction is the area where the northern Red Sea bifurcates into the Gulf of Aqaba and Gulf of Suez. Thirteen earthquakes located in the Triple Junction region are studied. Their initial source parameters are shown in Table 5. The best solution 
Table 5

Triple Junction seismic zone source parameters as reported in the ENSN catalog during the studied period

\begin{tabular}{|c|c|c|c|c|c|c|}
\hline Event no. & Event date (YYYY/MM/DD) & Time (hh:mm:ss) UTC & Latitude & Longitude & Depth $(\mathrm{km})$ & $M_{\mathrm{L}}$ \\
\hline 1 & $2011 / 02 / 20$ & $01: 27: 04$ & 27.6922 & 34.0586 & 18.2 & 4.9 \\
\hline 2 & $2011 / 02 / 20$ & $04: 52: 36$ & 27.6706 & 34.0684 & 17.8 & 4.4 \\
\hline 3 & $2011 / 06 / 30$ & $10: 50: 36$ & 27.6578 & 34.3491 & 10.3 & 3.7 \\
\hline 4 & $2011 / 11 / 19$ & $07: 12: 15$ & 27.6955 & 34.0602 & 15.0 & 4.6 \\
\hline 5 & $2011 / 11 / 20$ & $05: 16: 04$ & 27.6615 & 34.2423 & 15.9 & 4.2 \\
\hline 6 & $2012 / 01 / 30$ & $17: 04: 26$ & 27.6934 & 34.0645 & 9.6 & 5.2 \\
\hline 7 & $2012 / 01 / 31$ & $00: 46: 14$ & 27.7022 & 34.0647 & 4.7 & 3.6 \\
\hline 8 & $2012 / 01 / 31$ & $10: 24: 11$ & 27.7146 & 34.0082 & 9.5 & 3.7 \\
\hline 9 & $2012 / 06 / 02$ & $08: 13: 56$ & 27.6968 & 34.1135 & 9.1 & 4.1 \\
\hline 10 & $2012 / 06 / 10$ & 09:29:19 & 27.7135 & 34.1047 & 12.0 & 4.1 \\
\hline 11 & $2012 / 06 / 10$ & $12: 07: 10$ & 27.6992 & 34.0852 & 17.3 & 3.7 \\
\hline 12 & $2013 / 04 / 07$ & $15: 58: 01$ & 27.6899 & 34.0754 & 17.4 & 4.6 \\
\hline 13 & $2014 / 03 / 15$ & $11: 57: 53$ & 27.8517 & 34.6574 & 11.6 & 3.5 \\
\hline
\end{tabular}

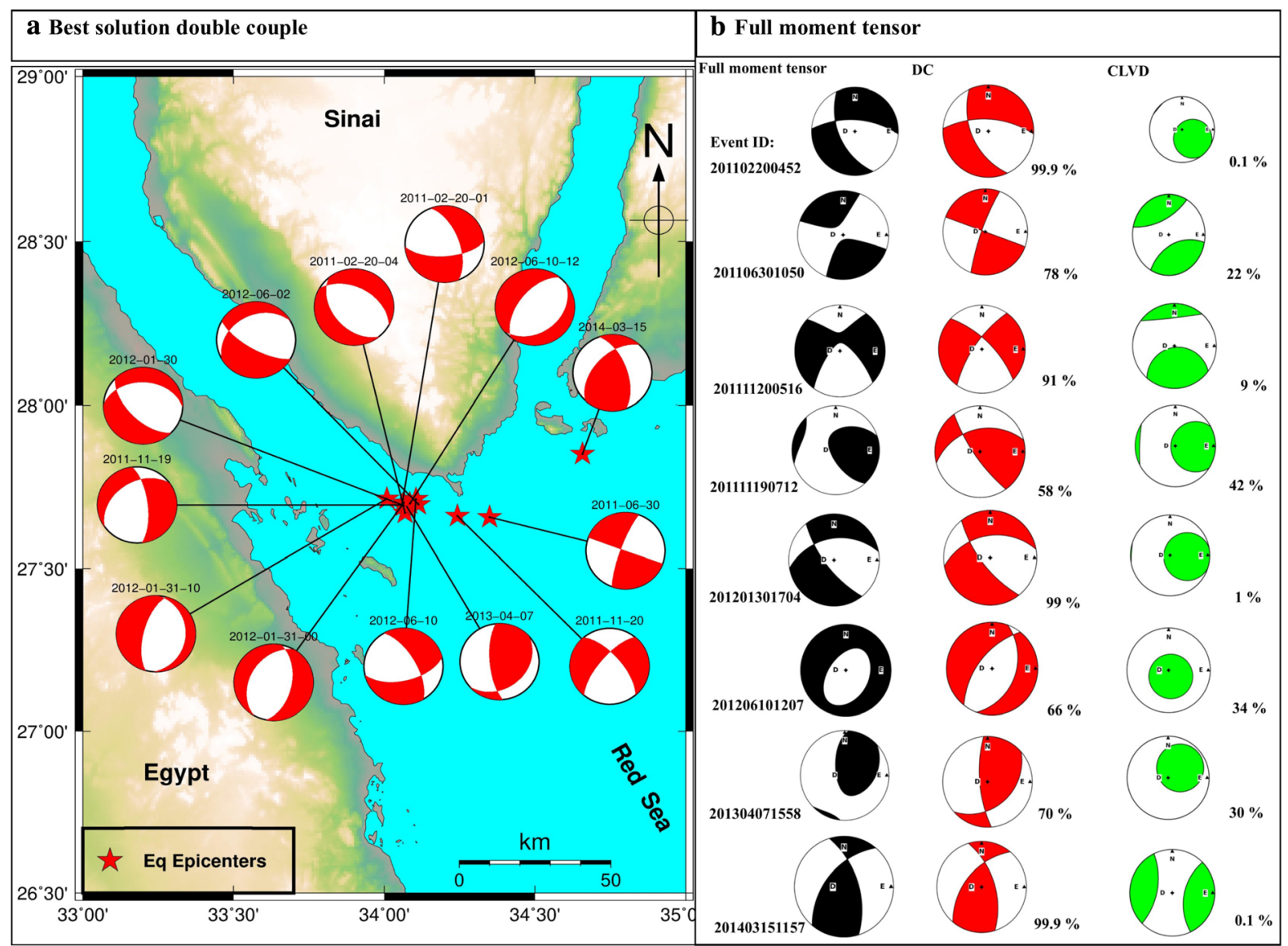

Figure 12

a Distribution of the best solution double-couple for earthquakes that occurred in the Triple Junction seismic zone. b From left to right, the complete moment tensor plot, the mechanism, and the percentage of its decomposed components 


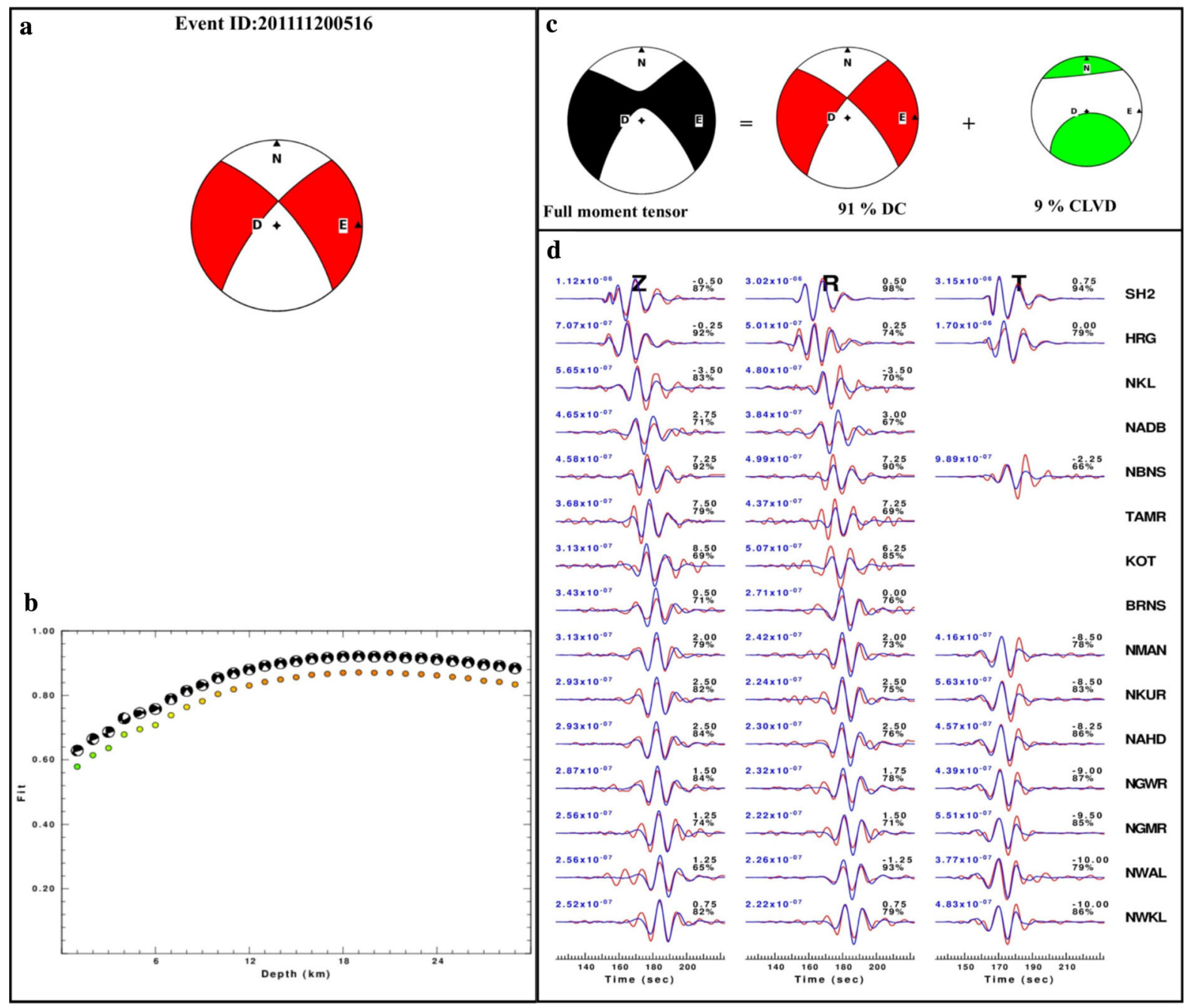

Figure 13

a Best solution double-couple, b depth fitting, $\mathbf{c}$ full moment tensor decomposition, (d) waveform fitting between observed and synthetic seismograms of the 20 November 2011 earthquake at 05:16 UTC in the Triple Junction area

double-couple mechanism reflected normal movement with minor strike-slip components for events with the epicenter located at the entrance of the Gulf of Suez and their nodal planes trending parallel to the main trend of the Gulf of Suez. In contrast, events located at the central area of the Triple Junction and at the entrance of the Gulf of Aqaba show a strikeslip mechanism with a sense of reverse motion (Fig. 12a). Figure 13a, b is an example of the obtained best double-couple mechanisms for the earthquake that took place on 20 November 2011 at 05:16 UTC. The detailed earthquake parameters such as scalar seismic moment, moment magnitude, goodness of fitting, best DC solution, and focal depth are summarized in Table 6 for this zone. Our findings are consistent with the tectonic setting and a recent source characteristic study about Triple Junction seismic activity (Abdel-aal and Yagi 2017; Badreldin et al. 2019; Abd el-aal and Badreldin 2016; Hussein et al. 2013). Full moment tensor solutions and the percentage of DC and CLVD components are given for earthquakes in this zone (Fig. 12b). The decomposed moment tensors for all events under study exhibited a high DC mechanism (66-99.9\%) with an 
Table 6

Fault planes for best solution double-couple and decomposition of Triple Junction earthquakes

\begin{tabular}{|c|c|c|c|c|c|c|c|c|c|c|c|c|c|}
\hline \multirow[t]{2}{*}{ Event no. } & \multicolumn{10}{|c|}{ Best solution double-couple } & \multicolumn{3}{|c|}{ Decomposition } \\
\hline & $M_{\mathrm{o}}(\mathrm{dyn}-\mathrm{cm})$ & $M_{\mathrm{w}}$ & Depth $(\mathrm{km})$ & Strike 1 & Dip 1 & Rake 1 & Strike 2 & Dip 2 & Rake 2 & Fitting variance & $\varepsilon$ & CLVD $(\%)$ & $\mathrm{DC}(\%)$ \\
\hline 1 & $2.5 \mathrm{E}+22$ & 4.2 & 14 & 86 & 64 & -146 & 340 & 60 & -30 & 0.3 & - & - & - \\
\hline 2 & $2.9 \mathrm{E}+22$ & 4.2 & 15 & 299 & 47 & -105 & 140 & 45 & -75 & 0.1 & 0.0 & 0.1 & 99.9 \\
\hline 3 & $4.3 \mathrm{E}+21$ & 3.7 & 23 & 110 & 90 & -10 & 199 & 80 & -179 & 0.3 & 0.1 & 21.9 & 78.1 \\
\hline 4 & $3.4 \mathrm{E}+22$ & 4.3 & 12 & 353 & 68 & -125 & 235 & 40 & -35 & 0.2 & 0.2 & 42.2 & 57.8 \\
\hline 5 & $2.7 \mathrm{E}+22$ & 4.2 & 19 & 220 & 70 & -25 & 319 & 67 & -158 & 0.1 & 0.0 & 8.9 & 91.1 \\
\hline 6 & $1.8 \mathrm{E}+23$ & 4.8 & 17 & 135 & 60 & -65 & 272 & 38 & -126 & 0.2 & 0.0 & 0.0 & 100.0 \\
\hline 7 & $1.0 \mathrm{E}+21$ & 3.3 & 15 & 11 & 52 & -102 & 210 & 40 & -75 & 0.5 & - & - & - \\
\hline 8 & $6.7 \mathrm{E}+20$ & 3.2 & 10 & 195 & 65 & -85 & 3 & 25 & -101 & 0.3 & - & - & - \\
\hline 9 & $6.3 E+21$ & 3.8 & 16 & 120 & 70 & -60 & 241 & 36 & -144 & 0.2 & - & - & - \\
\hline 10 & $4.6 \mathrm{E}+21$ & 3.7 & 17 & 330 & 65 & -35 & 76 & 59 & -150 & 0.2 & - & - & - \\
\hline 11 & $3.0 \mathrm{E}+21$ & 3.6 & 16 & 218 & 56 & -97 & 20 & 35 & -105 & 0.1 & 0.2 & 34.0 & 66.0 \\
\hline 12 & $2.5 \mathrm{E}+22$ & 4.2 & 17 & 175 & 70 & 65 & 49 & 32 & 139 & 0.2 & 0.2 & 30.2 & 69.8 \\
\hline 13 & $8.6 \mathrm{E}+21$ & 3.9 & 12 & 340 & 60 & 45 & 223 & 52 & 141 & 0.2 & 0.0 & 0.0 & 100.0 \\
\hline
\end{tabular}

average value of $83 \%$ accompanied by minor CLVD components (34-0.1\%) with an average value of $17 \%$, as listed in Table 6 and Fig. 12b). Figure 13c, d shows the full moment tensor decomposition example (c) and waveform fitting (d) for earthquakes that occurred on 20 November 2011 at 05:16 UTC time. A recent study carried out by Cochran (2005) proposed that the Triple Junction area is characterized by a high level of seismicity, which the author attributed to the broad tectonic activity and high heat flow where small cells of magma are just beginning to nucleate. Integration of our results with Cochran's (2005) findings may explain the minor non-DC components of the studied earthquakes in this zone. In general, the double-couple mechanism is a dominant characteristic for the studied earthquakes in the Triple Junction seismic zone.

\subsection{Red Sea Seismic Zone}

The best double-couple solutions for five earthquakes that took place in this zone indicate that the strike-slip movement is dominated by fault planes trending NNW-SSE and NNE-SW (Fig. 14a). The initial source parameters reported in the published catalog (Table 7) for the earthquakes under study in the Red Sea seismic zone, especially the focal depths and local magnitude, show significant differences from the obtained depths and moment magnitude that best fit the data with fitting goodness exceeding $70 \%$. The obtained parameters associated with the best fit such as fault plane solutions, focal depth, scalar seismic moment, and moment magnitude are summarized in Table 8. Figure 15a, b is an example of the obtained best DC solution for the 16 January 2014 earthquake at 13:02 UTC. Full moment tensor solution and decomposition of Red Sea earthquakes is dominated by a high DC component (78-91\%) with an average value of $84.5 \%$ associated with a low CLVD part (22-9\%) with an average value of $15.5 \%$, as presented in Fig. 14b and Table 8. In summary, the highest fitting between the observed and calculated waveforms exceeded $70 \%$ with a time shift less than $5 \mathrm{~s}$, and data with high SNR indicated that our result are accurate and robust. The obtained DC values for all earthquakes show that the Red Sea faulting follows a shear faulting mechanism. Figure $15 \mathrm{c}$, d describes an example of the full solution, decomposition (c), and waveform fitting (d) for earthquakes that occurred on 16 January 2014.

\subsection{Scattered Inland Seismicity Zone}

Northern Egypt has been subjected to three phases of tectonic deformation from the early Mesozoic to the present, as suggested by integrated subsurface studies supported by surface data (Bosworth et al. 2008; Korrat et al. 2005; Mosconi et al. 1996). Apart 
from the last tectonic phase from the late Eocene up to recent times, which took place along the Gulf of Suez fault trend (NNW), the Gulf of Aqaba rifting (NNE) and the NS trend of faults played a significant role in reactivating pre-existing inland faults (Moustafa et al. 1998). Ten scattering crustal earthquakes are examined. The initial parameters (local magnitude, depth, occurrence time) of inland earthquakes are presented in Table 9. The moment tensor solutions for the best double-couple exhibited many mechanisms that vary from one place to another in this zone (Fig. 16a). The first family exists in the western desert and includes six earthquakes, four of which have normal faulting, and the other two events exhibited strike-slip movement. The second group is the eastern desert family and includes three earthquakes, two of which show normal faulting, while the third one has a strike-slip mechanism. The third family is the Cairo-Suez district and involves one earthquake, which has a normal mechanism with minor strike-slip components. The best fitting results of the focal mechanism solution, focal depth, scalar

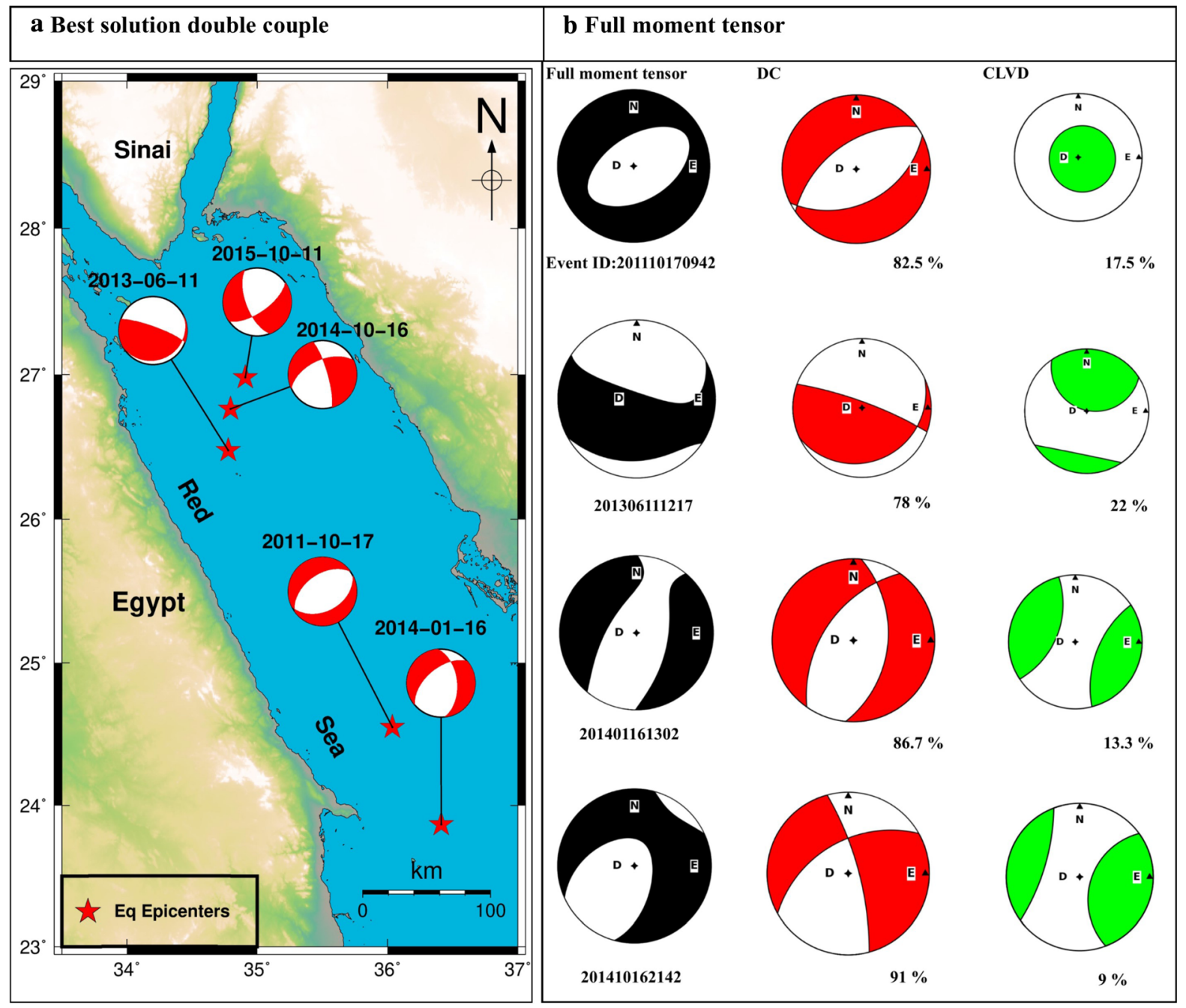

Figure 14

a The best solution double-couple distribution in the Red Sea seismic zone. b The full moment tensor solution with compressional field colored by black, and the percentage of its decomposing components, DC (shaded in red) and CLVD (shaded in green) 
Table 7

The fault plane initial parameters of selected Red Sea earthquakes as reported in the ENSN catalog during the studied period

\begin{tabular}{|c|c|c|c|c|c|c|}
\hline Event no. & Event date (YYYY/MM/DD) & Time (hh:mm:ss) UTC & Latitude & Longitude & Depth $(\mathrm{km})$ & $M_{\mathrm{L}}$ \\
\hline 1 & $2011 / 10 / 17$ & $09: 42: 27$ & 24.5502 & 36.0359 & 2.2 & 3.6 \\
\hline 2 & $2013 / 06 / 11$ & $12: 17: 40$ & 26.4802 & 34.7757 & 16.5 & 3.8 \\
\hline 3 & $2014 / 01 / 16$ & $13: 02: 38$ & 23.8654 & 36.4107 & 7.7 & 3.7 \\
\hline 4 & $2014 / 10 / 16$ & $21: 42: 37$ & 26.7635 & 34.7941 & 11.3 & 3.6 \\
\hline 5 & $2015 / 10 / 11$ & 11:01:10 & 26.9813 & 34.9087 & 29.6 & 3.7 \\
\hline
\end{tabular}

Table 8

Best solution double-couple and moment tensor decomposition obtained through the current study for Red Sea seismic events

\begin{tabular}{|c|c|c|c|c|c|c|c|c|c|c|c|c|c|}
\hline \multirow[t]{2}{*}{ Event no. } & \multicolumn{10}{|c|}{ Best solution double-couple } & \multicolumn{3}{|c|}{ Decomposition } \\
\hline & $M_{\mathrm{o}}(\mathrm{dyn}-\mathrm{cm})$ & $M_{\mathrm{w}}$ & Depth (km) & Strike 1 & Dip 1 & Rake 1 & Strike 2 & Dip 2 & Rake 2 & Fitting Variance & $\varepsilon$ & CLVD (\%) & $\mathrm{DC}(\%)$ \\
\hline 1 & $1.1 \mathrm{E}+22$ & 4.0 & 6 & 235 & 49 & -95 & 63 & 40 & -84 & 0.2 & 0.1 & 17.5 & 82.5 \\
\hline 2 & $9.4 \mathrm{E}+20$ & 3.3 & 14 & 290 & 80 & 100 & 64 & 14 & 45 & 0.3 & 0.1 & 22.0 & 78.0 \\
\hline 3 & $5.5 \mathrm{E}+21$ & 3.8 & 12 & 230 & 55 & -50 & 354 & 51 & -133 & 0.3 & 0.1 & 13.3 & 86.7 \\
\hline 4 & $1.2 \mathrm{E}+22$ & 4.0 & 13 & 344 & 78 & -144 & 245 & 55 & -15 & 0.3 & 0.0 & 9.0 & 91.0 \\
\hline 5 & $7.0 \mathrm{E}+21$ & 3.8 & 12 & 55 & 65 & -30 & 159 & 63 & -152 & 0.3 & - & - & - \\
\hline
\end{tabular}

seismic moment, and moment magnitude are listed in Table 10. Figure 17a, $\mathrm{b}$ shows the best solution focal mechanism for the earthquake that took place on 11 April 2013 at 03:56 UTC time. In order to broaden our knowledge about the source processes inland of Egypt, we calculated the full moment tensor for the earthquakes under investigation, and then decomposed them to DC and CLVD parts (Fig. 16b and Table 5b). The obtained full moment tensor solution improved the best solution DC misfit with goodness of fitting up to $80 \%$. Figure $17 \mathrm{c}$ and d displays an example of the full waveform solution and decomposition (c) and waveform fitting (d) of the mentioned earthquake. Our results indicated that the crustal earthquakes in Egypt follow the shear faulting mechanism with high DC solutions (74-96\%) with an average value of $88 \%$, as shown in Table 10 and Fig. 16b.

\section{Stress Drop Result}

Stress drop values are investigated to deeply study the source physics of triggered seismicity and tectonics (inter- and intraplate) earthquakes. Our estimated stress drop values for 1200 triggered earthquakes in the Aswan Reservoir area during the studied period from 2010 to 2017 match well with previous studies in the same target area (e.g., Saadalla et al. 2019; El-amin 2011; Hassib 1997), as illustrated in Table 11. In addition, it is comparable to worldwide cases. For example, Mandal et al. (1998) obtained a mean stress drop of $0.1 \mathrm{Mpa}$ for seismicity that took place in the Koyna Dam area, India. Fletcher (1982) obtained stress drop values ranging from 1.3 to $9.2 \mathrm{Mpa}$ for seismic events that occurred near the Monticello Reservoir in South Carolina, USA. Tables 11 and 12 summarize the stress drop values obtained in the current study with previous studies in the same target area and global cases, respectively. Huang et al. (2017) suggested that stress drops of tectonic and induced earthquakes are indistinguishable and noted that induced earthquakes are driven by tectonic stresses. We estimated stress drops of about 1200 small-moderate-magnitude triggered and natural earthquakes in Egypt. The observed stress drops for triggered earthquakes range from 0.02 to 23 Mpa with a median stress of $0.3 \mathrm{Mpa}$. In comparison, 


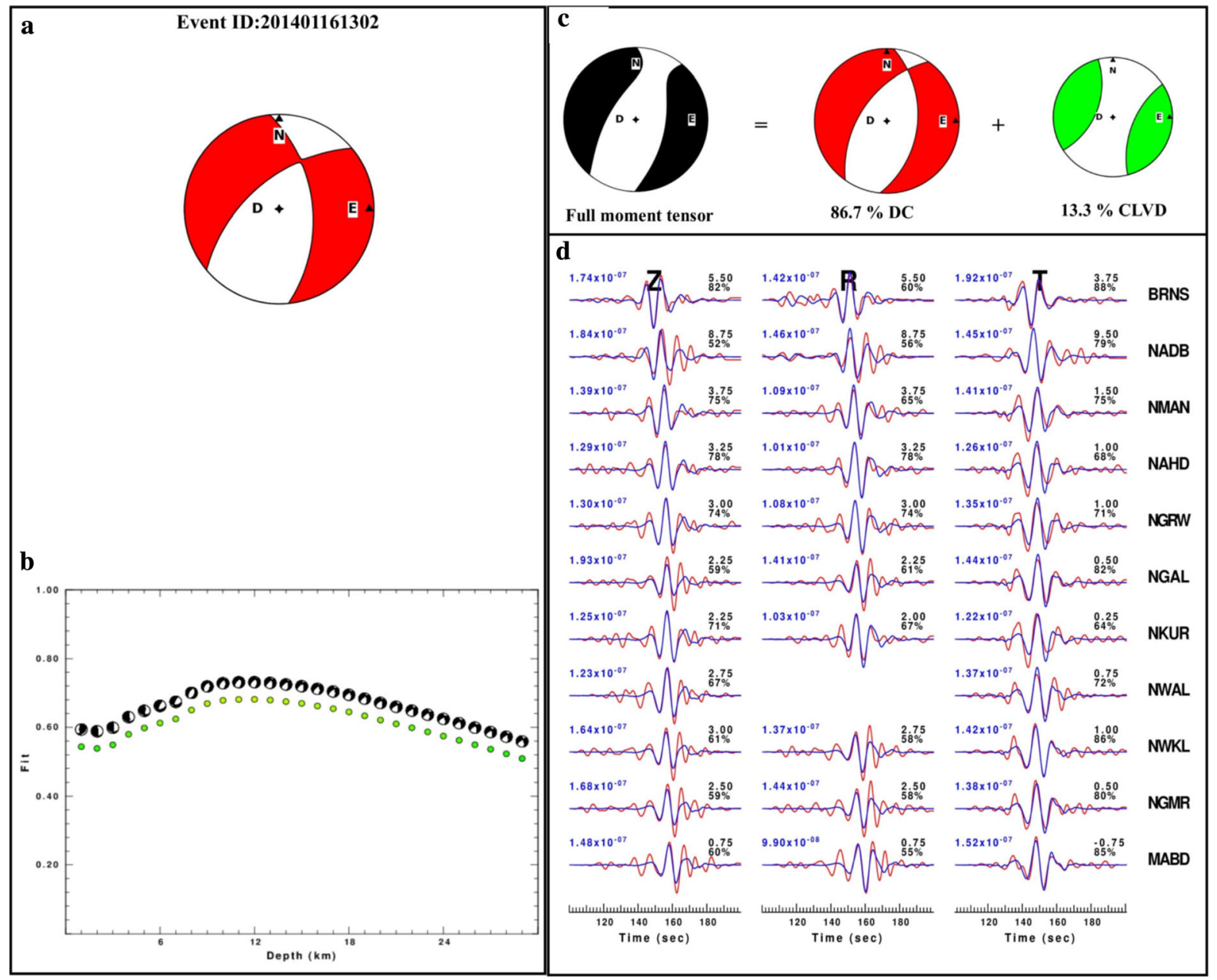

Figure 15

a The mechanism corresponding to the best fit double couple; $\mathbf{b}$ the focal mechanism for the best solution at each depth; $\mathbf{c}$ full moment tensor and its decomposed parts (DC and CLVD); d fitting between observed (red traces) and synthetic (blue traces) waveforms of 16 January 2014 earthquake at 13:02 UTC in the Red Sea

the stress drop values for 21 natural earthquakes calculated in this study and previous studies have stress drops ranging from 0.9 to $87 \mathrm{Mpa}$ with a median stress of $7.5 \mathrm{Mpa}$. Figure 18 shows the observed stress drop distribution over all studied zones. Supplementary -Material Tables S1 and S2 provide a complete list of the stress drop values obtained in this study for the triggered and the natural earthquakes, respectively. The estimated range of Brune stress drops may be influenced by several factors, including uncertainty in the corner frequency, the assumed value of rupture speed, source geometry, and focal depth error. The focal depth of $80 \%$ of the triggered events are shallower than $10 \mathrm{~km}$, while $80 \%$ of the tectonic earthquakes are deeper than $15 \mathrm{~km}$. The obtained stress drops did not exhibit any dependence on the earthquake depth for either triggered or natural earthquakes (Fig. 19). Possible causes for the low stress drop value obtained for the studied earthquakes are that the Aswan seismic region is considered as a reservoir-triggered earthquake area (Mohamed et al. 2009). It is characterized by frequently repeated earthquakes in the same patches with swarm character, and high pore fluid pressure is observed (Gahalaut and Hassoup 2012). The tensile faulting style with non-negligible positive 
Table 9

List of the initial hypocenter parameters of inland Egypt seismicity as assigned in the ENSN catalog during the studied period

\begin{tabular}{|c|c|c|c|c|c|c|}
\hline Event no. & Event date (YYYY/MM/DD) & Time (hh:mm:ss) UTC & Latitude & Longitude & Depth $(\mathrm{km})$ & $M_{L}$ \\
\hline 1 & $2010 / 10 / 28$ & 09:02:30 & 25.8544 & 31.9695 & 7.0 & 4.2 \\
\hline 2 & $2011 / 07 / 29$ & $16: 19: 23$ & 25.9552 & 31.9287 & 19.6 & 4.0 \\
\hline 3 & $2012 / 01 / 22$ & $20: 03: 32$ & 24.7311 & 31.7979 & 4.0 & 3.8 \\
\hline 4 & $2012 / 01 / 28$ & $06: 15: 41$ & 27.9945 & 32.6427 & 23.6 & 3.7 \\
\hline 5 & $2012 / 02 / 16$ & $02: 15: 10$ & 29.7324 & 30.6895 & 4.1 & 3.6 \\
\hline 6 & $2012 / 03 / 12$ & $02: 31: 34$ & 27.5925 & 33.0040 & 18.7 & 3.9 \\
\hline 7 & $2012 / 07 / 17$ & 01:27:02 & 24.4671 & 29.0401 & 4.1 & 3.7 \\
\hline 8 & $2013 / 04 / 11$ & 03:56:09 & 27.8088 & 33.4812 & 19.5 & 4.2 \\
\hline 9 & $2016 / 12 / 22$ & $22: 22: 28$ & 30.2641 & 31.9166 & 6.9 & 3.6 \\
\hline 10 & $2017 / 12 / 15$ & 08:49:21 & 28.0174 & 26.7448 & 0.0 & 4.0 \\
\hline
\end{tabular}

CLVD is observed throughout the previous part of the current study. The mentioned findings may explain the low stress drop values obtained in this study for earthquakes that took place in the Aswan seismic region.

\section{Conclusion}

We investigated full waveform moment tensor solutions for 46 earthquakes in and around Egypt, including six triggered seismic events that took place in the Aswan seismic zone and 40 earthquakes of natural origin such as in the Gulf of Aqaba, Triple Junction, Red Sea, and inland seismicity zones. In addition, the static stress drop for 1200 earthquakes including triggered and natural events were calculated based on the generalized inversion technique solved by the least square approach using P- and $\mathrm{S}$-wave displacement source spectra constrained by the reference site. The reliability of our results is evaluated based on the signal-to-noise ratio, time shift, and the misfit between the observed and calculated seismograms. Our findings were compared with previous studies in the same target area and worldwide cases. First, we derived the best solution double-couple, after which full moment tensor inversion was performed for all studied earthquakes. The best solution double-couple mechanism for Aswan earthquakes is governed by strike-slip movement with a minor normal component. Full moment tensors solutions reflected a non-negligible non-DC component for all earthquakes in the Aswan seismic zone, except the deepest earthquake of 19 September 2016, with depth of $25 \mathrm{~km}$. The observed non-negligible CLVD component for most events in the Aswan region used in this study cannot be used to discriminate in a strict sense between triggered and natural earthquakes. In spite of that, it gives an indicator for another source mechanism that has triggered seismicity in the Aswan region. Possible causes of a non-negligible CLVD component may be attributed to high pore fluid pressure in ancient preexisting complex intersected faults in stable continental areas Lake Nasser, Aswan. The other studied seismic zones of natural origin follow the shear faulting mechanism with a high DC part and a minor CLVD component. Based on Brune's (1970) and Madariaga's (1976) displacement source models, we observed that Aswan seismic events (triggered earthquakes) have stress drop values that ranged from 0.02 to $23 \mathrm{MPa}$ with a median stress of $0.3 \mathrm{MPa}$, in comparison with natural earthquakes which have static stress drop ranging from 0.9 to $87 \mathrm{MPa}$ and median stress of $7.5 \mathrm{Mpa}$. In conclusion, Aswan earthquakes have a non-negligible positive CLVD component which reflects tensile faulting. The pressure of pore fluid in ancient pre-existing orthogonal faults may be the causative factor for triggering seismicity in the study region. The studied earthquakes in the main target seismic zone of this research (Lake Nasser Reservoir) have lower stress drop and shallower focal depth than the studied natural events. Nevertheless, due to the difference in 


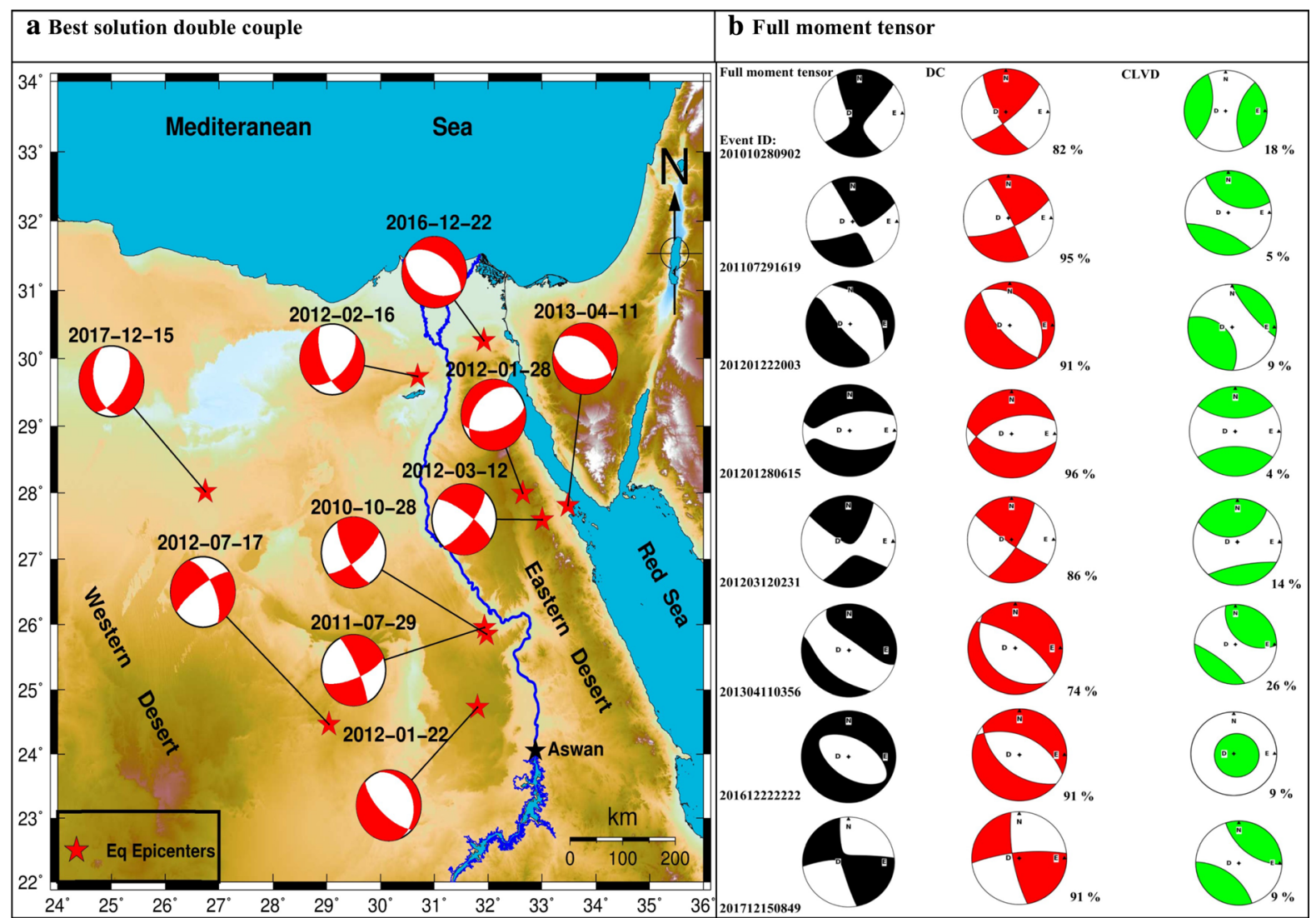

Figure 16

a Map showing the best double-couple solution. b From left to right, the complete moment tensor mechanism, the plot and the percentage of its decomposed parts for each earthquake selected in this zone

Table 10

Best fault plane mechanism for double-couple and moment tensor decomposition of inland Egypt seismicity obtained in this study

\begin{tabular}{|c|c|c|c|c|c|c|c|c|c|c|c|c|c|}
\hline \multirow[t]{2}{*}{ Event no. } & \multicolumn{10}{|c|}{ Best solution double-couple } & \multicolumn{3}{|c|}{ Decomposition } \\
\hline & $M_{\mathrm{o}}(\mathrm{dyn}-\mathrm{cm})$ & $M_{\mathrm{w}}$ & Depth (km) & Strike 1 & Dip 1 & Rake 1 & Strike 2 & Dip 2 & Rake 2 & Fitting variance & $\varepsilon$ & CLVD $(\%)$ & $\mathrm{DC}(\%)$ \\
\hline 1 & $4.3 \mathrm{E}+21$ & 3.7 & 10 & 53 & 71 & 159 & 150 & 70 & 20 & 0.2 & 0.1 & 17.6 & 82.4 \\
\hline 2 & $4.8 \mathrm{E}+21$ & 3.7 & 19 & 335 & 80 & -20 & 69 & 70 & -169 & 0.2 & 0.0 & 4.7 & 95.3 \\
\hline 3 & $1.2 \mathrm{E}+21$ & 3.3 & 20 & 133 & 67 & -101 & 340 & 25 & -65 & 0.6 & 0.0 & 9.0 & 91.0 \\
\hline 4 & $6.5 \mathrm{E}+20$ & 3.1 & 5 & 75 & 55 & -70 & 223 & 40 & -116 & 0.6 & 0.0 & 4.4 & 95.6 \\
\hline 5 & $1.5 \mathrm{E}+22$ & 4.0 & 15 & 45 & 50 & -35 & 159 & 64 & -134 & 0.4 & - & - & - \\
\hline 6 & $2.0 \mathrm{E}+21$ & 3.5 & 12 & 305 & 75 & -20 & 40 & 71 & -164 & 0.4 & 0.1 & 13.6 & 86.4 \\
\hline 7 & $8.2 \mathrm{E}+20$ & 3.2 & 9 & 235 & 75 & -30 & 333 & 61 & -163 & 0.5 & - & - & - \\
\hline 8 & $2.6 \mathrm{E}+21$ & 3.5 & 17 & 305 & 50 & -75 & 102 & 42 & -107 & 0.2 & 0.1 & 25.9 & 74.1 \\
\hline 9 & $9.4 \mathrm{E}+20$ & 3.3 & 6 & 305 & 50 & -85 & 117 & 40 & -96 & 0.4 & 0.0 & 8.9 & 91.1 \\
\hline 10 & $7.9 \mathrm{E}+20$ & 3.2 & 14 & 30 & 55 & -60 & 165 & 45 & -126 & 0.3 & 0.0 & 8.7 & 91.3 \\
\hline
\end{tabular}




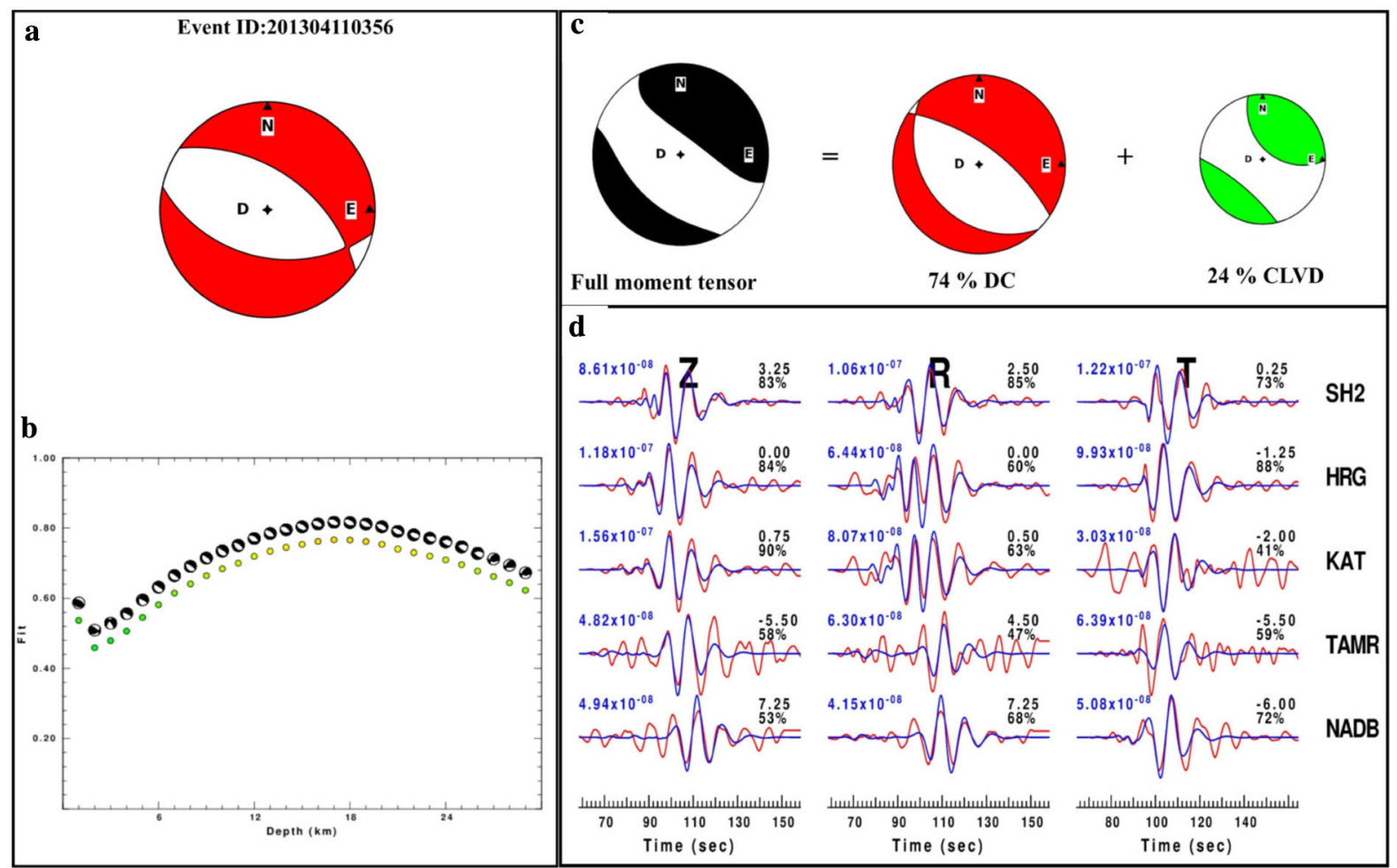

Figure 17

Example of the full moment tensor inversion a best solution DC, $\mathbf{b}$ depth fitting, $\mathbf{c}$ full moment decomposition and the percentage of its parts, d waveform fitting between observed (red traces), and synthetic (blue traces) seismogram of 11 April 2013 earthquake at 03:56 UTC in CairoSuez region

Table 11

Comparison between stress drop values obtained in this study and other studies in the same target area

\begin{tabular}{lllll}
\hline Author & $M_{\mathrm{L}}$ & $M_{\mathrm{o}}($ dyn-cm) & $\Delta \sigma(\mathrm{Mpa})$ & \multicolumn{1}{c}{$M_{\mathrm{w}}$} \\
\hline Saadalla et al. (2019) & $0.9-3.5$ & $1.5 \times 10^{17}-2.1 \times 10^{20}$ & $0.03-2.9$ & $1.4-3.3$ \\
El-amin (201) & $2.0-3.54$ & $0.97 \times 10^{20}-7.52 \times 10^{20}$ & $0.03-2.98$ & $1.9-3.54$ \\
Mohamed (2004) & $1.5-3.1$ & $4.37 \times 10^{18}-2.2 \times 10^{21}$ & $0.05-7.0$ & $1.55-2.86$ \\
Hassib (1997) & $1.9-3.4$ & $4.9 \times 10^{18}-8.1 \times 10^{21}$ & $0.02-14.2$ & - \\
Current study & $0.9-4.6$ & $1.5 \times 10^{16}-2.1 \times 10^{21}$ & $0.02-23$ & $1.1-4.0$ \\
\hline
\end{tabular}

Table 12

Comparison between stress drop values obtained in this study and other reservoir cases globally

\begin{tabular}{lllll}
\hline Region & $M_{\mathrm{o}}($ dyn-cm) & $\Delta \sigma(\mathrm{Mpa})$ & Magnitude range & Author \\
\hline Central United States (fluid injection) & - & $0.6-84$ & $3.3-5.8\left(\mathrm{M}_{\mathrm{w}}\right)$ & Huang et al. (2017) \\
Koyna-Warna, India & $10^{20}-10^{23}$ & $3-26$ & $3.5-5.2\left(\mathrm{M}_{\mathrm{L}}\right)$ & Yadav et al. (2013) \\
Acu reservoir, NE Brazil & $1.38 \times 10^{19}-5.02 \times 10^{19}$ & $26-179$ & $<2.1\left(\mathrm{M}_{\mathrm{L}}\right)$ & Tomic et al. (2009) \\
KTB Deep Drilling Site, Germany & $10^{14}-10^{18}$ & $0.01-6$ & $<1.2\left(\mathrm{M}_{\mathrm{L}}\right)$ & Jost et al. (1998) \\
Oroville Reservoir, California (USA) & $1.4 \times 10^{21}-3.3 \times 10^{21}$ & $1.4-17$ & $2.8-5.2\left(\mathrm{M}_{\mathrm{L}}\right)$ & Fletcher et al. 1984) \\
Monticello Reservoir, South Carolina (USA) & $1.7 \times 10^{20}-3.4 \times 10^{20}$ & $1.3-9.2$ & $2.8-3.0\left(\mathrm{M}_{\mathrm{L}}\right)$ & Fletcher 1982) \\
Aswan Reservoir, Egypt & $1.5 \times 10^{16}-2.1 \times 10^{21}$ & $0.02-23$ & $0.9-4.6\left(\mathrm{M}_{\mathrm{L}}\right)$ & Current study \\
\hline
\end{tabular}




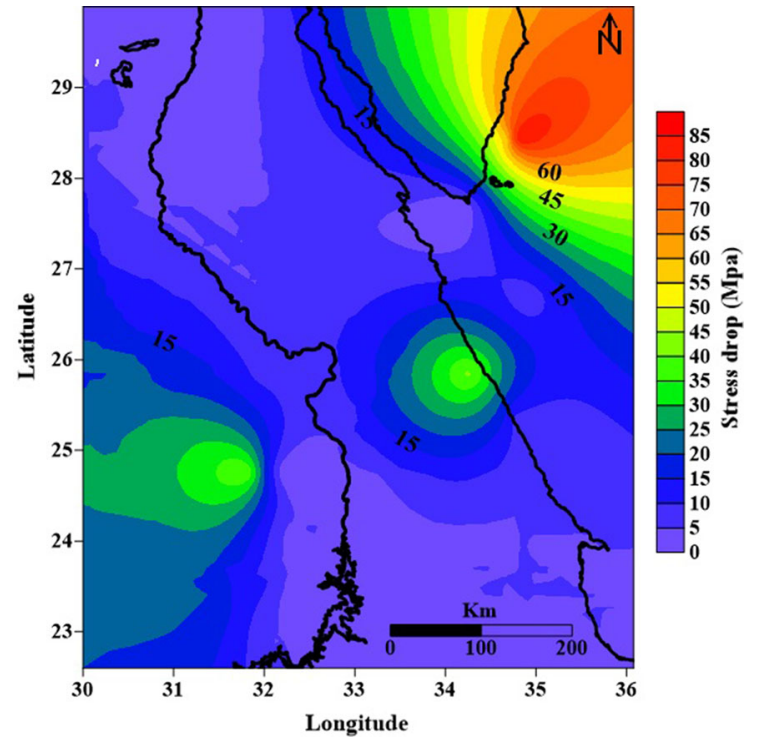

Figure 18

Stress drop distribution of the selected earthquakes in the Aswan seismic zone and other inter- and intraplate seismic zones in Egypt

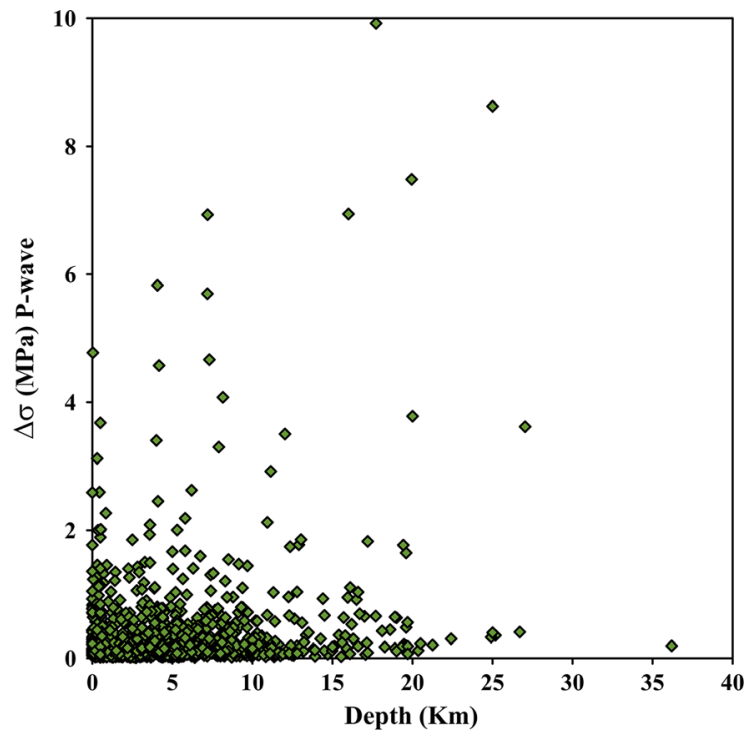

Figure 19

Plot of the relation between stress drop and earthquake depth obtained in the current study

magnitude size, focal depth, and tectonic setting between the triggered and natural earthquakes used in this study, the use of stress drop value and/or CLVD component for discriminating triggered earthquakes in the Aswan region from natural ones remains inconclusive and debatable.

\section{Acknowledgements}

We humbly extend our appreciation to our organization, the Aswan Earthquake Research Center, National Research Institute of Astronomy and Geophysics (NRIAG), for providing us with the earthquake data used in this study. The authors would like to sincerely express their deepest gratitude to Professor Robert B. Herman (Reinert Professor of natural sciences, Department of Earth and Atmospheric Sciences, Saint Louis University) for providing us with Computer Program in Seismology (CPS.330), his help, his support, his explanations, and his guidance. We would like to extend our heartfelt thanks to Dr. Hesham Mousa (Associate Professor of seismology at NRIAG) for his help in the revision of the manuscript and constructive comments. Our appreciation goes to our colleagues from our organization, who have contributed somehow, whether in data compilation, sharing, or discussion methods. We wish to thank Editor Dr. Fabio Romanelli and anonymous reviewers for their constructive comments and reviews.

Open Access This article is licensed under a Creative Commons Attribution 4.0 International License, which permits use, sharing, adaptation, distribution and reproduction in any medium or format, as long as you give appropriate credit to the original author(s) and the source, provide a link to the Creative Commons licence, and indicate if changes were made. The images or other third party material in this article are included in the article's Creative Commons licence, unless indicated otherwise in a credit line to the material. If material is not included in the article's Creative Commons licence and your intended use is not permitted by statutory regulation or exceeds the permitted use, you will need to obtain permission directly from the copyright holder. To view a copy of this licence, visit http://creativecommons.org/licenses/by/4. $0 \%$

Publisher's Note Springer Nature remains neutral with regard to jurisdictional claims in published maps and institutional affiliations. 


\section{REFERENCES}

Abd el-aal, A. K., \& Badreldin, H. (2016). Seismological aspects of the 27 June 2015 Gulf of Aqaba earthquake and its sequence of aftershocks. Journal of Seismology, 20(3), 935.

Abd el-aal, A. K., Mostafa, S. I., \& Abdelhafiez, H. E. (2019). Review of the seismotectonic setting of the Gulf of Aqaba with respect to the 27 June 2015 and the 16 May 2016 earthquake sequences. Pure and Applied Geophysics, 176, 541. https://doi. org/10.1007/s00024-018-2024-5.

Abdel-aal, A. K., \& Yagi, Y. (2017). Earthquake source characterization, moment tensor solutions, and stress field of smallmoderate earthquakes occurred in the northern Red Sea Triple Junction. Geosciences Journal, 21(2), 235-251.

Abdel-Fattah, A. K., Hussein, H. M., Ibrahim, E. M., \& El Atta, A. A. (1997). Fault plane solutions of the 1993 and 1995 Gulf of Aqaba earthquakes and their tectonic implications. Annals of Geophysics, 40(6), 1555-1564. https://doi.org/10.4401/ag-3831.

Abercrombie, R., \& Leary, P. (1993). Source parameters of small earthquakes recorded at $2.5 \mathrm{~km}$ depth, Cajon Pass, southern California: implications for earthquake scaling. Geophysical Research Letters, 20(14), 1511-1514.

Abou Elenean, K. M. (2003). Focal mechanism and stress tensor inversion of earthquakes at and around Nasser Lake, Egypt. Bulletin of Faculty of Science, Zagazig University, 25, 77-107.

Aki, K., Richards, P.G. (2002). Quantitative seismology (Vol. 1).

Andrews, D.J. (1986). Objective determination of source parameters and similarity of earthquakes of different size. Earthquake Source Mechanics, pp.259-267.

Backus, G., \& Mulcahy, M. (1976). Moment tensors and other phenomenological descriptions of seismic sources-I. Continuous displacements. Geophysical Journal International, 46(2), 341-361.

Badreldin, H., Abdel-aal, A. K., Toni, M., \& El-Faragawy, K. (2019). Moment tensor inversion of small-to-moderate size local earthquakes in Egypt. Journal of African Earth Sciences, 151, 153-172.

Ben-Avraham, Z. (1985). Structural framework of the Gulf of Elat (Aqaba), northern Red Sea. Journal of Geophysics Research, 90(B1), 703-762.

Bosworth, W., El-Hawat, A. S., Helgeson, D. E., \& Burke, K. (2008). Cyrenaican "shock absorber" and associated inversion strain shadow in the collision zone of northeast Africa. Geology, 36(9), 695-698.

Brune, J. N. (1970). Tectonic stress and the spectra of seismic shear waves from earthquakes. Journal of Geophysical Research, 75(26), 4997-5009.

Cesca, S., Rohr, A., \& Dahm, T. (2013). Discrimination of induced seismicity by full moment tensor inversion and decomposition. Journal of Seismology, 17(1), 147-163.

Cochran, J.R. (2005). Northern Red Sea: Nucleation of an oceanic spreading center within a continental rift. Geochemistry, Geophysics, Geosystems, 6(3).

Cuenot, N., Dorbath, C., \& Dorbath, L. (2008). Analysis of the microseismicity induced by fluid injections at the EGS site of Soultz-sous-Forêts (Alsace, France): implications for the characterization of the geothermal reservoir properties. Pure and Applied Geophysics, 165(5), 797-828.

Dziewonski, A. M., Chou, T. A., \& Woodhouse, J. H. (1981). Determination of earthquake source parameters from waveform data for studies of global and regional seismicity. Journal of Geophysical Research: Solid Earth, 86(B4), 2825-2852.

El-amin. (2011).Study of seismic hazard analysis using fault parameter solutions in Aswan region, Upper Egypt, Ph.D. Thesis, Faculty of Science, Assuit University, Egypt.

EL-Hadidy, S. (1995). Crustal structure and its related causative tectonics in northern Egypt using geophysical data. Ph. D. Thesis, Ain Shams University.

Eshelby, J.D. (1957). August. The determination of the elastic field of an ellipsoidal inclusion, and related problems. In: Proceedings of the Royal Society of London A: Mathematical, Physical and Engineering Sciences (Vol. 241, No. 1226, pp. 376-396). The Royal Society.

Eyre, T. S., Bean, C. J., De Barros, L., O’Brien, G. S., Martini, F., Lokmer, I., et al. (2013). Moment tensor inversion for the source location and mechanism of long period (LP) seismic events from 2009 at Turrialba volcano, Costa Rica. Journal of Volcanology and Geothermal Research, 258, 215-223.

Fairhead, J. D., \& Girdler, R. W. (1970). The seismicity of the Red Sea, Gulf of Aden and Afar Triangle. In: Philosophical Transactions of the Royal Society of London, Series A, Mathematical and Physical Sciences, (vol. 267, pp. 49-74).

Fehler, M., \& Phillips, W. S. (1991). Simultaneous inversion for Q and source parameters of micro earthquakes accompanying hydraulic fracturing in granitic rock. Bulletin of the Seismological Society of America, 81(2), 553-575.

Fitch, T. J., McCOWAN, D. W., \& Shields, M. W. (1980). Estimation of the seismic moment tensor from teleseismic body wave data with applications to intraplate and mantle earthquakes. Journal of Geophysical Research: Solid Earth, 85(B7), 3817-3828.

Fletcher, J. B. (1982). A comparison between the tectonic stresses measured in situ and stress parameters from induced seismicity at Monticello Reservoir, South Carolina. Journal of Geophysical Research, 87, 6931-6944.

Fletcher, J. B., Boatwright, J., Harr, L., Hanks, T., \& McGarr, A. (1984). Source parameters for aftershocks of the Oroville, California earthquake. Bulletin of the Seismological Society of America, 74, 1101-1123.

Fojtíková, L., Vavryčuk, V., Cipciar, A., \& Madarás, J. (2010). Focal mechanisms of micro-earthquakes in the Dobrá Voda seismoactive area in the Malé Karpaty Mts. (Little Carpathians), Slovakia. Tectonophysics, 492(1-4), 213-229.

Foulger, G. R., Julian, B. R., Hill, D. P., Pitt, A. M., Malin, P. E., \& Shalev, E. (2004). Non-double-couple microearthquakes at Long Valley caldera, California, provide evidence for hydraulic fracturing. Journal of Volcanology and Geothermal Research, 132(1), 45-71.

Gahalaut, K., \& Hassoup, A. (2012). Role of fluids in the earthquake occurrence around Aswan reservoir, Egypt. Journal of Geophysical Research: Solid Earth, 117(B2).

Gibowicz, S. J., Young, R. P., Talebi, S., \& Rawlence, D. J. (1991). Source parameters of seismic events at the Underground Research Laboratory in Manitoba, Canada: Scaling relations for events with moment magnitude smaller than-2. Bulletin of the Seismological Society of America, 81(4), 1157-1182.

Gilbert, F. (1971). Excitation of the normal modes of the Earth by earthquake sources. Geophysical Journal International, 22(2), 223-226.

Godano, M., Bardainne, T., Regnier, M., \& Deschamps, A. (2011). Moment-tensor determination by nonlinear inversion of 
amplitudes. Bulletin of the Seismological Society of America, 101(1), 366-378.

Goldstein, P. \& Snoke, A., (2005). SAC Availability for the IRIS Community. Incorporated Institutions for Seismology Data Management Center Electronic Newsletter, Vol. VII, and No. 1

Guilhem, A., Hutchings, L., Dreger, D. S., \& Johnson, L. R. (2014). Moment tensor inversions of $\mathrm{M} \sim 3$ earthquakes in the Geysers geothermal fields, California. Journal of Geophysical Research: Solid Earth, 119(3), 2121-2137.

Gupta, H. K. (2002). A review of recent studies of triggered earthquakes by artificial water reservoirs with special emphasis on earthquakes in Koyna, India. Earth-Science Reviews, 58(3-4), 279-310.

Hardebeck, J. L., \& Shearer, P. M. (2003). Using S/P amplitude ratios to constrain the focal mechanisms of small earthquakes. Bulletin of the Seismological Society of America, 93(6), 2434-2444.

Häring, M. O., Schanz, U., Ladner, F., \& Dyer, B. C. (2008). Characterization of the Basel 1 enhanced geothermal system. Geothermics, 37(5), 469-495.

Hassib, G.H., (1997). A study on the earthquakes mechanics around the High Dam Lake, Aswan,Egypt,Ph.D.Thesis,Faculty of Science, Sohag,SouthValley University

Hassib, G., Hamed, H., Dahy, S., Hassoup, A., \& Moustafa, S. (2010). Detection of the seismic quiescence along the seismic active faults in Kalabsha area, west of Lake Nasser, Aswan, Egypt. Acta Geodaetica et Geophysica Hungarian, 45(2), 210-226.

Herrmann, R. B. (2013). Computer programs in seismology: An evolving tool for instruction and research. Seismological Research Letters, 84(6), 1081-1088.

Herrmann, R. B., \& Wang, C. Y. (1985). A comparison of synthetic seismograms. Bulletin of the Seismological Society of America, 75(1), 41-56.

Hosny, A., Ali, S. M., \& Abed, A. (2014). Study of the 26 December 2011 Aswan earthquake, Aswan area, south of Egypt. Arabian Journal of Geosciences, 7(11), 4553-4562.

Huang, Y., Ellsworth, W. L., \& Beroza, G. C. (2017). Stress drops of induced and tectonic earthquakes in the central United States are indistinguishable. Science advances, 3(8), p. e1700772.Int. Science Advances, 3(8), e1700772. (Int. Inst. Seismol. Earthq. Eng. 19, 155-160).

Hussein, H. M., Elenean, K. A., Marzouk, I. A., Korrat, I. M., ElNader, I. A., Ghazala, H., et al. (2013). Present-day tectonic stress regime in Egypt and surrounding area based on inversion of earthquake focal mechanisms. Journal of African Earth Sciences, 81, 1-15.

Issawi, B. (1969). The Geology of Kurkur-Dungul Area, South Western Desert, General Egyptian Organization for Geological Research and Mining, Geological Survey, Paper No. 46.

Issawi, B. T. (1978). Geology of Nubia west area, western desert. Annals of the Geological Survey of Egypt, 3, 237-253.

Iwata, T., \& Irikura, K. (1988). Source parameters of the 1983 Japan Sea earthquake sequence. Journal of Physics of the Earth, 36(4), 155-184.

Jerris, T.J. (2014). Development of structural basins and domes on the Sinn El-Kaddab Plateau, Egypt: insights from in situ data and application of moderate resolution orbital imagery of the Seiyal Fault.
Jost, M. L., \& Herrmann, R. B. (1989). A student's guide to and review of moment tensor. Seismological Research Letters, 60(2), 37-57. https://doi.org/10.1785/gssrl.60.2.37.

Julian, B. R., Miller, A. D., \& Foulger, G. R. (1998). Non-doublecouple earthquakes 1. Theory. Reviews of Geophysics, 36(4), 525-549.

Kebeasy, R., \& Gharib, A. (1991). Active fault and water loading are important factors in triggering earthquake activity around Aswan Lake. Journal of Geodynamics, 14, 73-85. https://doi.org/ 10.1016/0264-3707(91)90010-C.

Kebeasy, R. M., Maamoun, M., Ibrahim, E., Megahed, A., Simpson, D. W., \& Leith, W. S. (1987). Earthquake studies at Aswan reservoir. Journal of Geodynamics, 7(3-4), 173-193.

Khalil, A. E., El-Hady, S. M., \& Hosny, A. (2004). Three-dimensional velocity structure of VP and VP/VS around Aswan area. Egypt. Journal of Applied Geophysics, 3(1), 303-314.

Knopoff, L., \& Randall, M. J. (1970). The compensated linearvector dipole: A possible mechanism for deep earthquakes. Journal of Geophysical Research, 75(26), 4957-4963.

Korrat, I. M., El Agami, N. L., Hussein, H. M., \& El-Gabry, M. N. (2005). Seismotectonic of the passive continental margin of Egypt. Journal of African Earth Sciences, 41(1-2), 145-150.

Krieger, L., \& Heiman, S. (2012). MoPaD-Moment tensor plotting and decomposition: A tool for graphical and numerical analysis of seismic moment tensors. Seismological Research Letters, 83(3), 589-595.

Kuge, K., \& Lay, T. (1994). Systematic non-double-couple components of earthquake mechanisms: The role of fault zone irregularity. Journal of Geophysical Research: Solid Earth, 99(B8), 15457-15467.

Lizurek, G. (2017). Full moment tensor inversion as a practical tool in case of discrimination of tectonic and anthropogenic seismicity in Poland. Pure and Applied Geophysics, 174(1), 197-212.

Maamoun, M. M., A. Megahed. \& A. Allam. (1984). Seismicity of Egypt, HIAG Bull., Vol. IV, ser. B.

Madariaga, R. (1976). Dynamics of an expanding circular fault. Bulletin of the Seismological Society of America, 66(3), 639-666.

Makris, J., \& Henke, C. H. (1992). Pull-apart evolution of the Red Sea. Journal of Petroleum Geology, 15(2), 127-134.

Mandal, P., Rastogi, B. K., \& Sarma, C. S. P. (1998). Source parameters of Koyna earthquakes, India. Bulletin of the Seismological Society of America, 88(3), 833-842.

Marzouk, I. (1988). Crustal structure of Egypt deduced from deep seismic and gravity data. Ph. D. thesis, Univ. of Hamburg, 118.

McGarr, A., Simpson, D., Seeber, L., \& Lee, W. (2002). Case histories of induced and triggered seismicity. International Geophysics Series, 81(A), 647-664.

Miller, A. D., Foulger, G. R., \& Julian, B. R. (1998). Non-doublecouple earthquakes 2. Observations. Reviews of Geophysics, 36(4), 551-568.

Mohamed, H. M. (2004). Determination of basic physical source parameters and scaling relations for Kalabsha earthquakes, Aswan. Egypt. Acta Geodynamica et Geromaterialia, 1(2), 201-213.

Mohamed, H. M., Bhattacharya, P. M., Kamal, S., \& Kayal, J. R. (2009). Seismicity and 3D velocity structure in the Aswan Reservoir Lake area. Egypt. Tectonophysics, 476(3-4), 450-459.

Mosconi, A., Rebora, A., Venturino, G. \& Bocca, P. (1996). EgyptNile Delta and North Sinai Cenozoic tectonic evolutionary model-A proposal. In 58th EAGE Conference and Exhibition. 
Moustafa, A.R., El-Badrawy, R., Gibali, H. \& Eloui, M. (1998). Pervasive E-ENE oriented faults in the northern Egypt and their relationship to Late Cretaceous petroliferous basins in the northern Western Desert. In: Proceedings of 14th Egyptian General Petroleum Corporation Exploration and Production Conference, Cairo (Vol. 1, pp. 51-67).

Pinar, A., \& Türkelli, N. (1997). Source inversion of the 1993 and 1995 Gulf of Aqaba Earthquakes. Tectonophysics, 283, 279-288.

Ross, A., Foulger, G. R., \& Julian, B. R. (1996). Non-doublecouple earthquake mechanisms at the Geysers geothermal area. California. Geophysical Research Letters, 23(8), 877-880.

Saadalla, Hamada, Abd el-aal, A. K., Abdelnasser, M., \& ElFaragawy, K. (2019). Determination of earthquake source parameters using the inversion of waveform data: A case of small earthquakes around High Dam Lake, Aswan region. Egypt. Journal of African Earth Sciences, 151, 403-416.

Said, Rushdi. (1962). The Geology of Egypt. Amsterdam and New York: Elsevier Publishing Company.

Sieberg, A. (1932). Untersnctuiigen uber Erdbeben und Bruchschollenbau Im Ostlichen Mittelmeergebiet, Denkschriften der medizinisch-Naturwis-Senchaftlichen. Gesellschaft zu Jene, 18(75-82), 235-238.

Simpson, D. W., Gharib, A. A., \& Kebeasy, R. M. (1990). Induced seismicity and changes in water level at Aswan reservoir, Egypt. Gerlands Beitr. Geophys. Leipzig, 99, 191-204.

Simpson, D. W., Kebeasy, R. M., Nicholson, C., Maamoun, M., Albert, R. N., Ibrahim, E. M. et al. (1986). Aswan telemetered seismograph network. Journal of Geodynamics, 7, 195-203.

Spikin, S. A. (1986). Estimation of earthquake source parameters by the inversion of waveform data: global seismicity, 1981-1983. Bulletin of the Seismological Society of America, 76(6), 1515-1541.

Stump, B. W., \& Johnson, L. R. (1977). The determination of source properties by the linear inversion of seismograms. Bulletin of the Seismological Society of America, 67(6), 1489-1502.

Telesca, L., Fat-Elbary, R., Stabile, T. A., Mohamed, M., \& ElGabry, M. (2017). Dynamical characterization of the 1982-2015 seismicity of Aswan region (Egypt). Tectonophysics, 712, 132-144.

Templeton, D. C., \& Dreger, D. S. (2006). Non-double-couple earthquakes in the Long Valley volcanic region. Bulletin of the Seismological Society of America, 96(1), 69-79.
Tomic, J., Abercrombie, R. E., \& Nascimento, A. F. (2009). Source parameters and rupture velocity of small MB2.1 reservoir induced earthquakes. Geophysical Journal International, 179(1013-1023), 15-832.

Udías, A., Madariaga, R. \& Buforn, E. (2014). Source mechanisms of earthquakes: Theory and practice. Cambridge University Press.

Vavryčuk, V. (2014). Iterative joint inversion for stress and fault orientations from focal mechanisms. Geophysical Journal International, 199(1), 69-77. https://doi.org/10.1093/gji/ggu224.

Vavryčuk, V. (2015). Inversion for the composite moment tensor. Bulletin of the Seismological Society of America, 105(6), 3024-3035.

Woodward-Clyde Consultants. (1985). Earthquake Activity and Dam Stability Evaluations for the Aswan High Dam, Egypt, vol. 3: Seismic Geology and Tectonic Studies of the Aswan Region, report to High Aswan Dam Authority, Ministry of Irrigation, A.R.E., under Contract No. 263-0102-c-00-HADA-00,USAID Project No.,263-0042-305 pp.

http://www.iris.edu

http://www.isc.ac.uk

www.gfz-potsdam.de

www.globalcmt.org

www.usgs.gov

Yadav, A., Shashidhar, D., Mallika, K., Rao, N. P., Rohilla, S., Satyanarayana, H. V. S., et al. (2013). Source parameters of earthquakes in the reservoir-triggered seismic (RTS) zone of Koyna-Warna. Western India. Natural hazards, 69(1), 965-979.

Youseff, M. M. (2003). Structural setting of central and south Egypt: An overview. Micropaleontology, Vol. 49. Micropaleontology, Supplement No. 1, 1-13. (text-figures 1-6).

Zhang, H., Eaton, D. W., Li, G., Liu, Y., \& Harrington, R. M. (2016). Discriminating induced seismicity from natural earthquakes using moment tensors and source spectra. Journal of Geophysical Research: Solid Earth, 121(2), 972-993.

Zhao, P., Kühn, D., Oye, V., \& Cesca, S. (2014). Evidence for tensile faulting deduced from full waveform moment tensor inversion during the stimulation of the Basel enhanced geothermal system. Geothermics, 52, 74-83.

Zhu, L., \& Helmberger, D. V. (1996). Advancement in source estimation techniques using broadband regional seismograms. Bulletin of the Seismological Society of America, 86(5), 1634-1641. 